\title{
Türk Basınında Büyük Nutuk’un Yansımaları
}

\section{Dr. Serap TAŞDEMİ**}

\begin{abstract}
$\ddot{O}_{z e t}$
Mustafa Kemal Paşa, Büyük Nutuk'u 15 Ekim 1927 tarihinde başlayan Cumhuriyet Halk Fırkası'nın İkinci Büyük Kongresi'nde, Fırka'nın Genel Başkanı ve Türkiye Cumhuriyeti Devleti'nin Cumhurbaşkanı sıfatıyla okumuştur. Gazi, 21 Ekim tarihine kadar, günde yaklaşık altı buçuk saat konuşarak, 1919'dan 1927'ye yaşananların genel bir değerlendirmesini yapmıştır. Nutuk, vermek istediği mesajla toplumda büyük yankılar uyandırmış, birçok alanda bilimsel çalışmaların konusu olmuş ve halen de olmaya devam etmektedir.

Bu araştırmada, 1919-1927 yıllarını kapsayan dönemde ülkenin ve basının durumu hakkında kısa bir değerlendirme yapıldıktan sonra, Mustafa Kemal Paşa'nın Büyük Nutuk'unu okuduğu tarihlerde yaygın ve yerel basında kamuoyuna

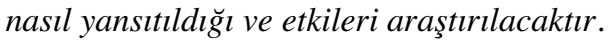

Anahtar Sözcükler: Büyük Nutuk, Mustafa Kemal Paşa, Yaygın Basında Büyük Nutuk, Yerel Basında Büyük Nutuk

\section{Effect of the Great Speech in the Turkish Press}

\begin{abstract}
The Effects of the Atatürk's Speech in the Turkish Press Mustafa Kemal Paşa delivered his Speech as the leader of the Republican People's Party and the President of the Republic in the Second General Congress of the Party that started on October 15, 1927. Gazi Mustafa Kemal Paşa completed his address on October 21, speaking approximately six and half hours a day, and evaluated the main content of what was experienced from 1919 to 1927. The messages given by the Speech caused great reflections among the people, the Speech has thus become subject to many scientific research up to the present..
\end{abstract}

* İnönü Üniversitesi, Fen-Edebiyat Fakültesi Tarih Bölümü, Malatya, stasdemir@inonu.edu.tr 
This study will first provide a short assessment of the country and the press between 1919 and 1927, and then will examine the reflections and effects of the Speech on the common and local press in the same period.

Key Words: The Great Speech, Mustafa Kemal Paşa, the Great Speech in Turkish Press

\section{GİRİş}

Cumhuriyet Halk Fırkası'nın İkinci Büyük Kongresinde Büyük Nutuk'u ${ }^{1}$ okuyan Mustafa Kemal Paşa, kongreyi izlemeye gelen Parti delegelerine, milletvekillerine, büyükelçilere, yabancı elçilik görevlilerine ve basın aracılığ $1 y l a$ tüm millete, gelecekte yapılacak hizmetlerden çok 19191927 yılları arasında neler yapıldığının hesabını vermiştir. ${ }^{2}$ Yaygın ve yerel basında ilgiyle izlenen Büyük Nutuk, sadece okunduğu tarihler arasında değil (15-20 Ekim 1927), öncesi ve sonrasında da gazetelerde gündem oluşturmaya devam etmiştir. ${ }^{3}$ Büyük Nutuk'un basındaki yankılarını değerlendirmeden önce 1919-1927 yılları arasında Türkiye'deki siyasal gelişmelere ve basında yaşanılan değişikliklere kısaca değinmek gerekmektedir. Böylece, Mustafa Kemal Paşa'nın Büyük Nutuk’u neden Cumhuriyet Halk Fırkası (CHF) büyük kongresinde okuduğunun yanıtı da bulunacaktır.

Dünyanın en ihtişamlı ve uzun ömürlü devletlerinden biri olan Osmanlı İmparatorluğu, 20. yüzyıla gelindiğinde eski gücünü koruyamamış, Birinci Dünya Savaşı'nın kaybedilmesinin ardından büyük güçler tarafından paylaşılmıştır. Ancak millet, İstanbul Hükümetince imzalanan Mondros Mütarekesi'ni kabul etmeyerek yaşamını imparatorluk yöneticilerinden farklı bir mecrada mücadeleye devam kararı alıp bağımsızlık savaşına başlamıştır.

Milli Mücadele'nin kıvılcımı Mustafa Kemal Paşa'nın Samsun'a çıkışıyla birlikte atılmış, Amasya Tamimi ve Erzurum Kongresi'nin ardından gerçekleştirilen Sivas Kongresi'nde Yeni Türkiye'nin temelleri

${ }^{1}$ Atatürk'ün bu nutkunun öteki söylevlerinden ayırt edilebilmesi için okuyucular tarafından Büyük Nutuk diye adlandırılması konusunda Bkz.: Enver Ziya Karal, "Açış Konuşması", Atatürk'ün Büyük Söylevi'nin 50. Yılı Semineri, Türk Tarih Kurumu, Ankara, 1980, s. 1.

2 Mustafa Kemal Paşa açılış konuşmasında hesap vereceğini şu sözlerle dile getirmiștir:"... senelerden beri devam eden efâl ve icraatımızın milletimize hesabını vermek vazifem olduğu kanaatindeyim...”. Akşam, 16 Teşrinievvel 1927, s. 1.

${ }^{3}$ Araştırmada, yaygın ve yerel basındaki gazetelerin 13-31 Ekim 1927 tarihleri arasındaki sayıları incelenmiştir. Büyük Nutuk ile ilgili haber vermeye devam eden Hâkimiyet-i Milliye gazetesinin 1-10 Kasım 1927 tarihleri arasındaki sayıları da araştırmaya dahil edilmiştir. 
oluşturulmuştur. ${ }^{4}$ İstanbul'un işgal edilmesinin ardından Ankara'da toplanan Büyük Millet Meclisi, Anadolu hareketine kamuoyunda meşruiyet sağlarken, aynı zamanda İstanbul Hükümeti karşısında ulusal bir merkez olmuştur. ${ }^{5}$

Türkiye Büyük Millet Meclisi toplanırken amaç siyasal iktidarı ele geçirmek yerine ülkeyi işgalcilerden kurtarmak olduğundan dolayı üyeler mecliste siyasal parti oluşturmayacaklarına dair karar almışlardı. Buna rağmen, Türkiye Komünist Partisi, Halk İştirakiyun Partisi gibi partiler kurulmuş, Birinci ve İkinci Grup ortaya çıkmıştır. Mustafa Kemal Paşa liderliğindeki Birinci Grup, sonradan Cumhuriyet Halk Fırkası'na dönüşmüş̧ ve tarihsel süreçte kendisini Anadolu ve Rumeli Müdafaa-i Hukuk Cemiyeti'nin devamı şeklinde temellendirmiştir. ${ }^{6}$ Cemiyetin kurulduğu Sivas Kongresi (4-11 Eylül 1919) ilk kongre, partinin kuruluş tarihi de İzmir'in kurtuluşunun birinci yılı seçilmiştir. ARMHC örgütleri bu dönem Halk Fırkası örgütüne katılmış, kurulduğu günden başlayarak Halk Fırkası ${ }^{7}$ ülkenin resmi partisi olmuştur. ${ }^{8}$ İkinci Grup ise seçimlere grup olarak katılmadığı gibi bireysel aday da göstermemiş/gösterememiştir. ${ }^{9}$ Ülkenin düşman işgalinden kurtuluşuna değin işgal kuvvetleri ve İstanbul Hükümeti'ne karşı tek vücut olan Milli Mücadele'nin önder kadrosu içindeki fikir ayrılıkları saltanatın kaldırılması ve özellikle Cumhuriyet'in ilanıyla birlikte su yüzüne çıkmıştır. ${ }^{10}$ Mustafa Kemal Paşa'nın ulusal önder

${ }^{4}$ Anadolu'da özellikle Ermeni ve Rum tehlikesinin ortaya çıktı örgütlenmeye gidilmiş, bu yerel örgütler Sivas Kongresi'nin ardından Anadolu ve Rumeli Müdafaa-i Hukuk Cemiyeti(ARMHC) adı altında birleşmişlerdir. Bu birleşmeye rağmen Anadolu'daki hareket, tek ve ulusal bir merkez olmayı ancak Büyük Millet Meclisi açıldıktan sonra sağlamıştır. Hakkı Uyar, Tek Parti Dönemi ve Cumhuriyet Halk Partisi, Boyut Yayınları, İstanbul, 1999, s. 60.

5 İhsan Güneş, Birinci TBMM’nin Düşünce Yapısı (1920-1923), Türkiye İş Bankası Yayınları, Ankara, 1997, s. 55-71.

${ }^{6}$ ARMHC ülkeyi düşmandan kurtarmıştı. Kurtuluşu ve bağımsızlığı kazanarak milleti mutlu eden "kadro", onun devamı olan Cumhuriyet Halk Firkası adıyla milleti ve devleti bağımsız bir şekilde yaşamasını sağlayacak, ülkeyi geri kalmışlıktan kurtararak modernleştirecekti. Hakkı Uyar, Tek Parti Dönemi ve Cumhuriyet Halk Partisi, s. 69-75.

1923 yilında yapılan seçimler sonrasında 11 Eylül 1923 tarihini kuruluş tarihi kabul eden Halk Fırkası, Terakkiperver Cumhuriyet Fırkası'nın kuruluşundan bir hafta önce, 10 Kasım 1924 tarihinde ismini "Cumhuriyet Halk Fırkası" olarak değiştirdi. 4. Büyük Kurultay (1935)'daki nizamnamenin birinci maddesinde ise ismi Cumhuriyet Halk Partisi olarak kabul edildi. Tarık Zafer Tunaya, Türkiye'de Siyasal Partiler 1859-1952, İstanbul, 1952, s. 560; Hikmet Bila, CHP Tarihi 1919-1979, Doruk Matbaacılık, Ankara, 1979, s. 65.

${ }^{8}$ Mete Tunçay, "Cumhuriyet Halk Partisi (1923-1950)", Cumhuriyet Dönemi Türkiye Ansiklopedisi, C. 8, İletişim Yayınları, İstanbul, t.y., s. 2019.

${ }_{9}$ Ihsan Güneş, a.g.e., s. 5-100.

${ }^{10}$ Birinci Büyüik Millet Meclisi milletvekilleri, Anadolu ve Rumeli Müdafaa-i Hukuk Cemiyeti üyelerinden oluşmuştur. Farklı toplumsal yapılardan gelen milletvekillerinin farklı ideolojik yaklaşımlarının mücadeleyi olumsuz etkilemesinin önüne geçmek için Sivas Kongresi'nde alınan "Her türlü fırkacılıktan" uzak durulması kararı BMM içinde partileşmenin önünü kapamış, ancak bu karara rağmen Meclis’te birçok gruplaşmalar ve hizipleşmeler oluşmuş̧ur. Başlangıç aşamasında oluşan bu gruplar sonraki zamanlarda -bağımsızlar dışında- kendilerini Birinci Grup ve İkinci Grup adıyla ifade etmiştir. Hakkı Uyar, Tek Parti Dönemi ve Cumhuriyet Halk Partisi, s. 61. 
kimliğiyle yönetimi biçimlendirme gücünü kabul ettirmesi önderler kadrosu içindeki dağılımı etkilemiştir. ${ }^{11}$ Milli Mücadele yılları boyunca yerel önderler, ulusal önderler kadrosu ve ulusal önder şeklinde üçe ayrılabilen önderlik, Mustafa Kemal Paşa'nın ulusal ölçekte önder ve başkomutan unvanını Gazi Paşalıktan ayrılmaksızın genişletmesine yol açmıştır.

1923 yılında yapılan seçimler sonucu 437 Birinci Meclis üyesinden 125 'i yeniden seçilirken, milletvekillerinden 114'ü Birinci Gruba mensuptur. Böylesi bir ortamda, Saltanatın ve halifeliğin kaldırılmasına muhalif olanların da katılımıyla ${ }^{12} 17$ Kasım 1924'de Kazım Karabekir Paşa başkanlığında Terakkiperver Cumhuriyet Fırkası kurulmuştur. Halk Fırkası'ndan istifa eden milletvekilleri de bu partinin etrafında birleşmiştir. ${ }^{13}$

1925 yılında meydana gelen Şeyh Sait İsyanı sonucu Takrir-i Sükûn Yasası çıkarılmış, devamında İstiklal Mahkemeleri kurulmuş, ${ }^{14} 3$ Haziran 1925 'de Terakkiperver Cumhuriyet Firkası kapatılarak siyasal muhalefete son verilmiştir. Bu dönemde toplum yapısını derinden etkileyecek bir dizi radikal reform gerçekleştirilmiştir. ${ }^{15}$ Ülkede ardı ardına yaşanan toplumsal değişimlerin kabulünde ${ }^{16}$-Mustafa Kemal Paşa'nın Büyük Nutuk’ta belirttiğgi gibi- Takrir-i Sükûn Kanunu önemli katkılar sağlamıştır. ${ }^{17}$

Ziya Hurşit yönetiminde, Cumhurbaşkanına yapılacak suikast girişiminin ortaya çıkarılması sonrasında hem eski İttihatçılar, hem de Terakkiperver Fırka'nın ileri gelenleri yargılanmış; gelişmelerle bir anlamda muhalefet tasfiye edilmiş, muhalif lider adayları da siyaset sahnesinin s. 242 .

${ }^{11}$ Erik Jan Zürcher, Modernleşen Türkiye’nin Tarihi, İletişim Yayınları, İstanbul, 2001,

${ }^{i 2}$ Hakkı Uyar, “Atatürk Dönemi İç Politikası”, Yakın Dönem Türk Politik Tarihi, Anı Yayıncılık, Ankara, 2006, s. 54. İkinci Grup üyeleri, İttihatçılar ve sosyalistlerle bir araya gelip örgütlü bir şekilde seçime girme kararı alamamış, Mustafa Kemal Paşa karşıtlarının oluşturduğu İkinci Grup ne kendisine başkan seçebilmiş ne de bir seçim bildirgesi yayınlayabilmiştir. Dolayısıyla da seçimlerde başarı gösteremediler. İhsan Güneş, Birinci TBMM'nin Düşünce Yapısı (1920-1923), s. 99-100.

13 Ahmet Demirel, "Birinci Mecliste İktidar ve Muhalefet", Yeni Türkiye Dergisi Cumhuriyet Özel Sayısı, IV/23-24, (Eylül-Aralık 1998), s. 308-310. 236.

${ }^{14}$ Erik Jan Zürcher, Milli Mücadelede İttihatçılık, Bağlam Yayınları, İstanbul, 1995, s.

${ }^{15}$ Saltanatın kaldırılması, Cumhuriyetin ilanı, halifeliğin kaldırılması gibi siyasal gelişmeleri, 1925 ve 1926 yılında yapılan Şapka Kanunu, Tekke ve zaviyelerin kapatılması, Hukuk Fakültesi'nin açılması, takvim ve saatin değiștirilmesi, yeni Medeni Kanun ile Ceza Kanunu gibi günlük hayatı ilgilendiren sosyal ve külttürel inkılâplar bu dönemde uygulanmaya başlamıştır. Kemal H. Karpat, Türk Demokrasi Tarihi, Afa Yayınları, İstanbul, 1996, s. 61 Feroz Ahmad, Modern Türkiye'nin Olușumu, Kaynak Yayınları, İstanbul, 1999, s. 75-76.

${ }^{16}$ Feroz Ahmad, Bir Kimlik Peşinde Türkiye, (Çev: Sedat Cem Karadeli), İstanbul Bilgi Üniversitesi Yayınları, İstanbul, 2006,s. 106; Emre Kongar, "Söylev Hangi Koşullar Altında Söylendi”, Türk Dili Dergisi, Söylev Özel Sayısı, XXXVI/314 (1 Kasım 1977), s. 376-377.

${ }^{17}$ Kemal Atatürk, Nutuk 1919-1927, Bugünkü Dille Yayına Haz.: Zeynep Korkmaz, Atatürk Araştırma Merkezi, Ankara, 2006, s. 605-606. 
dışında kalmıştır. ${ }^{18}$ İkinci Büyük Millet Meclisi, yukarıda özetlenen siyasal gelişmelerle süresini Temmuz ayında tamamlamıștır. 1927 yılı Eylül ayında yapılan seçimleri "Gazi Mustafa Kemal" imzasıyla halka sunulan Cumhuriyet Halk Fırkası adayları kazanmıştır. ${ }^{19}$ Yeni Meclis'in 1 Kasım 1927'de açılmasından önce toplanan Cumhuriyet Halk Fırkası'nın ilk büyük kongresinde Büyük Nutuk okunmuştur. ${ }^{20}$

Bu dönem basında yaşanan gelişmeler değerlendirildiğinde:

Milli Mücadele döneminde basın Ankara ve İstanbul Hükümetini destekleyenler şeklinde ikiye ayrılabilir. İstanbul gazeteleri içinde Milli Mücadele'yi destekleyenler, karşısında olanlar ve ayrıca Anadolu'daki direniş eylemine sempatiyle yaklaşanlar vardı. ${ }^{21}$ Anadolu'daki basında da benzer bir yaklaşım görülmüştür. Babalık (Konya), Albayrak (Erzurum), Öğ̈̈t (Afyonkarahisar/Konya-Ankara), Açısöz (Kastamonu), Irrade-i Milliye (Sivas), Hâkimiyet-i Milliye (Ankara) ve İzmir'e Doğru (Balıkesir) gibi gazeteler Milli Mücadele'yi desteklerken, Ferda (Adana), İrşat (Balıkesir) ve Zafer (Kastamonu) gibi gazeteler İstanbul Hükümetinin yanında yer almıştır. ${ }^{22} \mathrm{Bu}$ dönemde, Anadolu'da çıkan gazetelere sansür uygulanmazken, ${ }^{23}$ İstanbul'da örfi idare ve sansür basını ezmiştir. İstanbul'un milli kuvvetler tarafından kurtarılması üzerine alınan ilk tedbirlerden biri örfi idare ve sansürün kaldırılması olmuştur. ${ }^{24}$

Milli Mücadele devam ederken 8 Nisan 1920 günü halkı bilgilendirmek ve kamuoyu oluşturmak amacıyla kurulan Anadolu Ajansı, 7 Haziran 1920 tarihinde çalışmaya başlayan Matbuat ve İstihbarat Dairesi'ne bağlanmıştır.

${ }^{18}$ Erik Jan Zürcher, Terakkiperver Cumhuriyet Fırkası (1924- 1925), İletişim Yayınları, İstanbul, 2007, s. 132; Erik Jan Zürcher, Milli Mücadelede İttihatçılık, s. 236.

${ }_{19}$ Ücüncü dönem meclisinin milletvekillerini belirlemek amaciyla 23 Haziran 1927'de CHF'de bir tüzük değişikliği yapılmıştır. Buna göre, parti başkanı, milletvekili adaylarını tek başına belirleme yetkisine sahip olmuştur. 1927 yılında yapılan seçimlerde -seçim öncesi yapılan tüzük değişikliğinin de etkisiyle- meclis daha homojen ve bağlı bir kimliğe kavuşmuştur. Hasan Ünder, "Atatürk İmgesinin Siyasal Yaşamdaki Rolü”, Modern Türkiye'de Siyasi Düşünce: Kemalizm, C. 2., İletişim Yayınları, İstanbul, 2001, s. 142.

${ }^{20}$ Sabahattin Selek, "Atatürk ve Büyük Nutuk", "Nutuk" Nedir, Ne Değildir, Der.:Ahmet Köklügiller, IQ Kültür Sanat Yayıncilık, İstanbul, 2005, s. 54.

${ }^{21}$ Ileri, Yeni Gün, Akşam ve Vakit gibi gazeteler Milli Mücadele'yi desteklerken, Peyam-l Sabah, Alemdar ve Türkçe İstanbul gazeteleri şiddetle Milli Mücadele'ye saldırmıştır. Tasvir-i Efkar, İstiklal, İkdam ve Tercüman-1 Hakikat ise sempatiyle yaklaşmıștır. Hıfzı Topuz, II. Mahmut'tan Holdinglere Türk Basın Tarihi, Remzi Kitabevi, İstanbul,2003, s. 98.

${ }_{22}$ İzzet Öztoprak, Kurtuluş Savaşı'nda Türk Basını, Türkiye İş Bankası Kültür Yayınları, Ankara, 1981, s. 8-13.

${ }_{23}$ Milli Mücadele'yi destekleyen Anadolu basınına İstanbul hükümeti ve işgal kuvvetlerince baskı yapılmıștı. Örneğin Konya'da yayın yapan Öğ̈̈t gazetesi, 26 Ocak 1920 tarihinde, İngiliz yüksek komiserinin emriyle baskına uğramış ve matbaası tahrip edilmiş̧ti. Alpay Kabacalı, Başlangıçtan Günümüze Türkiye'de Basın Sansürü, Gazeteciler Cemiyeti, İstanbul, 1990, s. 109.

${ }^{24}$ Turhan Feyzioğlu, “Türk Basınının Kaderi”, Demokrasiye ve Diktatörlüğe Dair, İstanbul Matbaacılık, İstanbul, 1957, s. 107. 
Savaş yılları boyunca Anadolu harekâtının sesi olan Anadolu Ajansı, savaş bittikten sonra da Cumhuriyet rejimi ve devrimlerin kamuoyuna aktarılmasında önemli görevler üstlenmiştir. ${ }^{25}$

Milli Mücadele'nin kazanılması sonucu yaşanan sükûnet ortamı, saltanatın kaldırılması(na), Cumhuriyet'in ilanına tepkiler, Lozan barış görüşmelerindeki tartışmalar(da) ve Mecliste İkinci Grubun oluşması gibi olaylarda İstanbul'daki basın daha çok muhalefetin yanında yer almıştır. ${ }^{26}$ İstanbul basınındaki fikri yaklaşımlar Türk devrimine ve ulus bilincine zarar vermeye başlamış ve bu durum Ankara tarafından hoş karşılanmamıştır. 1617 Ocak 1923 tarihinde İstanbullu gazetecilerle yapılan İzmit Basın Toplantısı, hükümetin basından beklentileri konusunda ilk uyarı niteliği taşırken, gerçekte büyük çatışma Ağa Han'ın, İsmet Paşa'ya yolladığı saltanatın kaldırılmasını kınayan mektubun İsmet Paşa'ya ulaşmadan bazı İstanbul gazetelerinde yayınlanmasıyla başlamıştır. İstanbul'a gönderilen İstiklal Mahkemesi'nde ünlü gazeteciler yargılanmış, Lütfi Fikri Bey'in yargılama sonucu aldı ̆̆ı mahkûmiyet özel bir kanunla affedilmiştir. Gazetecilerden Velid (Ebuzziya), Cahid, Ahmet Cevdet, Hayri Muhittin ve Ömer İzzettin Beyler 1923 yılı sonunda yargılanmış ve 1924 yılı başında beraat etmişlerdir. Böylece bir yandan kamuoyu yatıştırılırken, diğer yandan basına “Türk Devrimi"nin kararlılığı ve/veya basından beklentileri ifade edilmiştir. ${ }^{27}$ Devam eden süreçte, Şeyh Sait ayaklanması nedeniyle 4 Mart 1925 'de çıkarılan Takrir-i Sükûn Kanunu, hükümete basın üzerinde tasarrufta bulunma hakkını vermiştir. Bu kanunla Terakkiperver Fırka'yı destekleyen Tevhid-i Efkâr, Tanin, Vatan, Aydınlık, Orak Çekiç gazeteleri başta olmak üzere İstanbul'daki en önemli gazete ve dergilerden sekizi ile ${ }^{28}$ yerel basında Sada-yı Hak (İzmir), Doğru Söz (Mersin), Kahkaha (Trabzon), İstikbal (Trabzon), Sayha (Adana) ve Yoldaş (Bursa) gazeteleri kapatılmıştır. Toksöz gazetesi yazarı Şükrü Oğuz ile Doğru Söz gazetesini çıkaran Ata Çelebi birer yıl hapis cezasına çarptırılmıştır. ${ }^{29}$ Gazeteciler genelde beraat ederken, 15 yıla kadar hapse mahkûm edilenler de vardır. ${ }^{30} \mathrm{Bu}$ dönem ortadan kalkan muhalif basın yerine İstanbul'da yayın yapan İkdam, Vakit ve Akşam gazetelerine ek olarak Cumhuriyet ve Milliyet gazeteleri çıkarken,

${ }^{25}$ Turgut Er, Türkiye'de Basın Yayın ve Tanıtma, Basın-Yayın ve Enformasyon Genel Müdürlüğüu, Ankara, 2003, s. 41

${ }^{26}$ Tarık Zafer Tunaya, Türkiye'de Siyasal Partiler, C. 3, İletişim Yayınları, İstanbul, 2007, s. 708; Orhan Koloğlu, Osmanlı'dan 21. Yüzyıla Basın Tarihi, Pozitif Yayınları, İstanbul, 2006, s. 114-116; Erik Jan Zürcher, Modernleşen Türkiye'nin Tarihi, s. 243-244

${ }^{27}$ Tarik Zafer Tunaya, Türkiye'de Siyasal Partiler, s. 708; Ergun Aybars, Istiklal Mahkemeleri, C. 1-2, Dokuz Eylül Üniversitesi Yayınları, İzmir, 1988, s. 239.

${ }^{28}$ Erik Jan Zürcher, Modernleşen Türkiye'nin Tarihi, s. 251

${ }^{29}$ Alpay Kabacalı, Başlangıçtan Günümüze Türkiye'de Basın Sansürü, s.115-120. 140 .

${ }^{30}$ Alpay Kabacalı, Türk Basınında Demokrasi, Kültür Bakanlığı, Ankara, 1994, s. 136- 
Ankara'da Hâkimiyet-i Milliye gazetesi yayınına devam etmiştir. ${ }^{31}$ Böylece basında genelde her türlü elestiriden, özellikle yıkıcı muhalefetten uzak, yapıcı bir dil ve hava hâkimdir. ${ }^{32}$

Yaygın basında yaşananlar bu şekilde cereyan ederken yerel basına ${ }^{33}$ bakıldığında: Milli Mücadele döneminde önemli görevler üstlenen yerel basın ${ }^{34}$ Cumhuriyet'in ilan edilmesinden sonra çalışmalarına devam etse de Milli Mücadele yıllarında gösterdiği başarıyı yakalayamamıștır. Yerel gazeteler -taşradaki gazetelerin bir kısmının resmi vilayet gazetesi olmasının da etkisiyle $e^{35}$ - kamuoyunun dördüncü gücü olmaktan ziyade bürokrasiye ilişkin bilgiler, merkez ve taşranın yüksek bürokratlarına övgüler ile İstanbul gazetelerinden $^{36}$ ve Anadolu Ajansı'ndan aktarılan makale ve haberlerle sayfalarını doldurmuş, yayınlandıkları yerlerde -genelde- İstanbul gazetelerinin önüne geçememişlerdir. ${ }^{37}$

1927 yılına gelindiğinde, yaygın ve yerel basın yapılan çağdaşlaşma hareketlerinin ve yaşanan değişimin kamuoyuna benimsetilmesinde hükümete büyük destek vermiştir. ${ }^{38}$ Toplumdaki okuma yazma oranının

${ }^{31}$ Orhan Koloğlu, Osmanlı'dan Günümüze Türkiye'de Basın, İletişim Yayınları, İstanbul, 1992, s. 64-65.

${ }_{32}$ Atatürk İzmir'de yaptığı konuşmada basından beklediklerini:: “Türk matbuatı, milletin hakiki sada ve iradesinin tecelligah olan Cumhuriyetin etrafinda çelikten bir kale vïcuda getirecektir. Bu fikir kalesi, zihniyet kalesi...Erbabr matbuattan bunu talep, Cumhuriyetin hakkldir. Bugün milletin samimi olarak müttehit ve mütesanit bulunmasi zaruridir. Umumun selameti ve saadeti bundadır. Mücadele bitmemiștir. Bu hakikati milletin kulağına, milletin vicdanına lüzumu gibi isalde matbuatın vazifesi çok ve çok mühimdir" sözleriyle dile getirmiștir. Atatürkçülü̈k (Birinci Kitap): Atatürk'ün Görüş ve Direktifleri, Milli Ĕgitim Basımevi, İstanbul, 1988, s. 314

${ }^{33} \mathrm{Bu}$ çalışmada, Türkiye içi ve dışı dağıtımı yapılan gazetelere yaygın basın denirken; sınırları dar ve tanımlanmış bir yörede, yöre halkını bilgilendirmeye, eğitmeye, eğlendirmeye, böylece kamuoyunun serbestçe oluşmasına katkıda bulunmaya gayret eden kitle iletişim araçları da yerel basın şeklinde tanımlanmıştır.

${ }^{34}$ Kağıt, mürekkep, matbaa harfleri gibi malzemenin yok denecek kadar eksik olduğu bu dönemde Anadolu'da basın, her türlü yokluk ve yoksunluk içinde çalışmıştır. Yaşanan olanaksızlıklar nedeniyle gazete ve dergiler kimi zaman ambalaj kâğıtlarına basılmış, kimi zaman da boyları küçültülmüş/ sayfa șayıları azalmıştır. Buna rağmen gazeteler görevlerini yerine getirmeye devam etmiş̧ir. İzzet Öztoprak, Kurtuluş Savaşı'nda Türk Basını, s. 30-31.

${ }^{35}$ Ali Tartanoğlu, “Atatürk Dönemi Türk Basınının Niteliği”, Baskın Basın’ın, Çağdaş Gazeteciler Derneği, Ankara, 1994, s. 99,

${ }_{36}$ Vilayet gazeteleri yayınlanmaya başladığı zaman İstanbul gazetelerinden alınan haberlerin özetlenerek yayınlanması durumu Cumhuriyet döneminde de devam etmiştir. Bu uygulamayı açıklamak için -altın makas- deyimi kullanılmıştır. Hediyetullah Aydeniz, "Tarihsel ve Literal Açıdan Yerel Gazetecilik", Türkiye'de Yerel Basın, İstanbul Üniversitesi İletişim Fakültesi Yayınları, İstanbul, 2007, s. 17.

${ }^{37}$ Osmanlı döneminde basının ve gazeteciliğin merkezi İstanbul olmuştur. Taşraya gönderilen İstanbul gazetelerinin o bölgedeki yerel gazetelerden daha çok ilgi görmesi durumu Cumhuriyet döneminde de devam etmiştir. Büyük Nutuk'un okunduğu dönemde İstanbul gazeteleri yanında Ankara'da Hâkimiyet-i Milliye gazetesi de taşrada etkilidir.

${ }^{38}$ Murat Sadullah Çebi, “Türkiye'de Siyasal Sistem ve Medya İlişkilerinin Tarihi Boyutu", Yeni Türkiye Dergisi Cumhuriyet Özel Sayısı, IV/23-24, (Eylül-Aralık 1998), s. 2748. 
azlığı ve gazete satın alıp okuyabilecek insanların da -gazetelerin ülkenin her yanına rahatça dağıtılamadığı için- gazete alamamaları nedeniyle hükümet basına ekonomik katkı sağlamıştır. ${ }^{39}$ Ö̇zel reklâmların az olduğu bir zamanda resmi ilan dağıtımı ve kâğıt satışı devlet aracılı̆̆ıyla düzenlenmiştir. ${ }^{40}$ Yine tüm basım araç gerecinin dışalımı ve taşradaki devlet basımevlerinden yerel gazetelerin yararlandırılması da, basın ile yönetim ilişkilerinin seyrine yön vermiştir. Bu dönemdeki gazete sahipleri veya başyazarlarının çoğu milletvekilidir. ${ }^{41}$ Yunus Nadi (Anadolu'da Yeni Gün, Cumhuriyet), Asım ve Hakkı Tarık Us Kardeşler (Vakit, (Kurun) Son Saat), Celal Nuri İleri (İleri), Mahmut Soydan (Milliyet-Tan), Falih Rıfkı Atay (Hâkimiyet-i Milliye), Necmeddin Sadak (Akşam), Ferit Celal Güven (Yeni Adana, Türk Sözü), Haydar Rüştü Öktem (Anadolu ve Duygu) bu gazetecilere örnek verilebilir. Muhalefet yapmayan belli başlı gazetelerin sahip ya da yazarları en az iki, üç -kimileri beş dönem- parlamentoda bulunmuştur. ${ }^{42}$

Büyük Nutuk'un okunduğu 15-20 Ekim 1927'de İstiklal Mahkemeleri kaldırılmış (7 Mart 1927), Takrir-i Sükûn Kanunu iki yıl daha uzatılmasına rağmen pek uygulanmamıştır. ${ }^{43}$ Cumhuriyet Halk Fırkası tek ve toplumu kucaklayıcı bir partidir. ${ }^{44}$ Büyük Nutuk'un yayınlandı̆̆ı dönemde basın genelde Mustafa Kemal Paşa'nın birleştirici ve yol gösterici kimliği etrafında toplanarak bir bütün oluşturmuştur.

Gazi Mustafa Kemal Paşa, Büyük Nutuk’un hazırlık aşamasındaki yoğun çalışmalarından dolayı geçirdiği kalp spazmı nedeniyle ${ }^{45^{3}}$-doktorların dinlenme tavsiyesine uyarak- 16 Mayıs 1919'da ayrıldı̆̆ı İstanbul'a sekiz yıl

${ }^{39}$ Milli Mücadele döneminden itibaren basına başta para yardımı olmak üzere çeşitli vasıtalarla destek olunmustur. Bu yardımlar yıllara göre: 1920' 2.500, 1921'de 75.689, 1922 'de $106.806,1923$ 'de $106.805,1924$ 'de $136.390,1925$ 'de $616.688,1926$ 'da 554.655 , 1927 'de 494.068 liradır. Para yardımları yanında gazetelere kâğıt, hurufat ve diğer malzeme yardımları da yapılmıştır. Nurettin Güz, Türkiye'de Basın-İktidar İlişkileri (1920-1927), Turhan Kitabevi, Ankara, 2008, s. s. 111-112.; Fethi Kardeş, 60 Yılın Hikayesi, Ankara, 1980, s. 19.

${ }^{40}$ Orhan Koloğlu, Osmanlı'dan Günümüze Türkiye'de Basın, s. 65.

${ }^{41}$ Ali Tartanoğlu, Baskın "Basın"ın, s. 105.

${ }^{42}$ Uygur Kocabasoğlu, “1919-1938 Dönemi Basınına Toplu Bakıș”, A.̈̈. Siyasal Bilgiler Yıllı̆̆ 1981, Ankara, 1982, s. 112 (95-127); Uygur Kocabaşoğlu, makalesinde 19201938 yılları arasında Büyük Millet Meclisi'nde görev yapan basın mensuplarının tam listesini 126-127. sayfalarda vermiștir.

${ }^{43}$ Mete Tunçay, Cumhuriyet Dönemi Türkiye Ansiklopedisi, s. 2021.

${ }^{44}$ Tarık Zafer Tunaya, Türkiye'de Siyasal Partiler 1859-1952, s. 560.

${ }^{45}$ Prof. Dr. Yuluğ Tekin Kurat, Gazi Mustafa Kemal Paşa'nın, Büyük Nutku Cumhuriyet Halk Fırkası Kurultayı'ndan önce Haziran ayında okumak isteğini, hazırlık aşamasındaki yoğun çalışmalardan dolayı geçirdiği kalp spazmı nedeniyle ertelenerek Ekim ayındaki CHF kongresinde okunduğunu dile getirirken, Izmir'de yayınlanan Anadolu gazetesi nisan ayından beri Mustafa Kemal Paşa'nın CHF kongresinde tarihi nutkunun okunacağını belirtir. Yuluğ Tekin Kurat "Büyük Nutuk'un Okunduğu Yılın Türkiyesi: 1927”, 70. Yılında Ullusal ve Uluslararası Boyutlarıyla Atatürk'ün Büyük Nutuk'u ve Dönemi, Orta Doğu Teknik Üniversitesi, Ankara, 1999, s. 171. 
sonra 1 Temmuz 1927 tarihinde yeniden gitmiş, ${ }^{46}$ İstanbul'da kaldığ 1 süre boyunca askerlikten emekliye ayrılmıș, 3 . Dönem için yapılan iki dereceli seçimleri de İstanbul'da(n) izlemiştir. ${ }^{47} 30$ Eylül'e kadar orada kalan Paşa, ${ }^{48}$ bu zaman diliminde önemli bir bölümünü belgelere dayanarak Ankara'da kaleme aldığı Büyük Nutuk'un son bölümlerini İstanbul'da yazıp düzeltmeleri yapmıştır. ${ }^{49}$

Büyük Nutuk'un okunmasını yaygın ve yerel basın büyük bir ilgiyle karşılamıştır. ${ }^{50}$ Öyle ki verilen haberlere bakıldığında CHF Kongresi'ni bile gölgede bırakmıştır. Daha A ğustos ayında Büyük Nutuk'la ilgili haberler gazete sayfalarını süslemiş, ${ }^{51}$ yaygın basında 13 ve 14 Ekim günlerinde Kongre ve Mustafa Kemal Paşa'nın Büyük Nutku'nu 15 Ekim günü başlayacak kongrede okuyacağı duyurulmuştur. ${ }^{52}$ Büyük Nutuk okunmadan önce, kamuoyu basın tarafından bilgilendirilerek hazır hale getirilmiştir.

Mustafa Kemal Paşa, siyasi bir lider olarak "Ben ne yaptım, niye yaptım, nasıl yaptım, kimlerle yaptım, karşıma kimler çıktı?"53 sorularına

${ }^{46}$ Utkan Kocatürk, Doğumundan Ölümüne Kadar Kaynakçalı Atatürk Günlüğ̈̈̈, Atatürk Araştırma Merkezi, Ankara, 2007, s. 399-400; Büyük Nutuk'un hazırlık çalışmalarındaki yoğunluk konusunda hem Afet İnan'ın, hem Ruşen Eşref'in, hem de diğerlerinin belirlemeleri konusundaki uyarıları taşıyan sohbetleri için Prof. Dr. Sadık Tural'a teşekkür ederim. Sadık Tural, "Büyük Nutuk'un Sahibi Yüce Şahsiyet", 10 Kasım 2007 Atatürk'ü Anma Töreni Konusmaları, Atatürk Arastırma Merkezi Yayınları, Ankara, 2008, s. 5-11, 31-32, 49, 57,7173, 77-78; Afet İnan, Atatürk Hakkında Hatıralar ve Belgeler, Türkiye İş Bankası Yayınları, 2007, s. 440-451,

${ }_{47}$ Mustafa Kemal Paşa'nın İstanbul'a geldiğini haber veren 1 Temmuz tarihli gazeteler haberi oldukça süslü bir şekilde verirler. Mete Tunçay, Türkiye Cumhuriyeti'nde Tek Parti Yönetiminin Kurulması 1923-1931, Tarih Vakfı, İstanbul, 2005, s. 180.

${ }^{48}$ İsmet Giritli, "Okunuşunun 75. Y1lında Büyük Nutuk", Yetmişbeşinci Yılında Büyük Nutuk'u Anlayarak Okumak Bilgi Şöleni (17-18 Ekim 2002 Ankara), Atatürk Araştırma Merkezi, Ankara, 2003, s. 5. Yaşanan bu sağlık sorunu nedeniyle söylevin sonraki kısımlarının özet şeklinde aktarıldığı görülür. Mete Tunçay, Türkiye Cumhuriyeti’nde Tek Parti Yönetiminin Kurulması 1923-1931, s. 180.

${ }^{49}$ Afet İnan, Atatürk Hakkında Hatıralar ve Belgeler, s. 441.

${ }^{50}$ Kaynak olarak yaygın basında Akşam, Cumhuriyet, Hâkimiyet-i Milliye, İkdam, Milliyet ve Vakit gazeteleri ile yerel basında -kütüphanelerde sayılarına ulaşılabilen- Açısöz, Ahenk, Amasya, Babalık, Balıkesir, Bartın, Cankırı, Güzel İnebolu, Haber, Hizmet, Hür Fikir, Kızılırmak, Malatya, Mamuratül Aziz, Milli Gazete, Tarsus, Urfa, Yeşil Giresun ve Yozgat gazeteleri incelenmiştir.

${ }_{51}$ Basın, Mustafa Kemal Paşa'nın Büyük Nutuk’unu Cumhuriyet Halk Fırkası kongresinde okuyacağına dair haberleri Ağustos ayında duyurmuştur. İsmail Arar, "Büyük Nutkun Kapsamı, Niteliği, Amacı”, Atatürk'ün Büyü̈k Söylevinin 50. Yllı Semineri, Türk Tarih Kurumu Yayınları, Ankara, 1980, s. 125; İzmir'de yayınlanan Anadolu gazetesi ise Atatürk'ün kongrede tarihsel bir nutuk vereceğinin Nisan ayından beri beklendiğini dile getirmiştir. Zeki Arıkan, "Büyük Söylev'in Yankıları", “Nutuk” Nedir, Ne Değildir, Der.:Ahmet Köklügiller, IQ Kültür Sanat Yayıncıllk, İstanbul, 2005, s. 408.

${ }_{52} 13$ Ekim tarihli Milliyet gazetesinde haber "Firka Kongresi İstihzarat Hitam Buldu" 14 Ekimdeki yazıda ise "Cumhuriyet Halk Fırkası Kongresi Yarın Sabah Küşad Edilecektir." cümleleriyle verilmiştir. Milliyet, 13-14 Teşrin-i Evvel 1927, s. 1.

${ }_{53}^{3}$ Sadık Tural, "Aydınlar Büyük Nutuk'u Anlayarak Yeniden Okusalar", Yetmissbesinci Yılında Büyük Nutku Anlayarak Okumak, Bilgi Şöleni 17-18 Ekim 2002 Ankara, Atatürk Araştırma Merkezi Yayınları, Ankara, 2003, s. VII-XI. 
açıklık getirdiği Büyük Nutuk'unu okumaya 15 Ekim günü başlamış ve 20 Ekim günü tamamlamıştır. ${ }^{54} 15$ Ekim tarihinden itibaren yaygın basında nutukla ilgili haberler ayrıntılı bir şekilde ele alınmıştır.

\section{Ulusal-Yaygın Basında Büyük Nutuk}

Yaygın basında gazeteler kongrenin ilk günü ile ilgili ayrıntılı bilgi vermekten daha çok genel değerlendirmeler yapmışlar, asıl haberleri 16 Ekim tarihinden itibaren okuyucularına aktarmışlardır. Ankara'da yayınlanan Hâkimiyet-i Milliye gazetesi ${ }^{55}$ ilk günden itibaren konuları İstanbul'da yayınlanan diğer gazetelere ve yerel basına göre daha ayrıntılı ele almıştır.

15 Ekim tarihli Hâkimiyet-i Milliye gazetesinde Cumhuriyet Halk Fırkası'nın yapacağı kongre "Cumhuriyet Halk Firkası'nın İlk Kongresi Bugün Onda Millet Meclisi'nde Umumi Reis Gazi Hazretleri Tarafindan Küşad olunacaktır" başlığıyla okuyuculara ilk sayfanın yarısı ayrılarak duyurulurken, ${ }^{56}$ Cumhuriyet gazetesi ilk günü okuyucularına: "Saat dokuzu çeyrek geçe bir kita asker geldi. Ve bahçe kapısından itibaren binanın önünde üç sıra teşkil etti. Biraz sonra musiki takımı göründü. Ve kıtanın başında mevki aldı. İçeride yukarı kat localarında bazı mebusların aileleri ve daha bazı davetli hanımlar göze çarpıyor..." sözleriyle betimlemiştir. ${ }^{57}$ Milliyet gazetesinin yarım sayfa ayırdığı haber: "Cumhuriyet Halk Fırkasi'nın Bugün Ankara'da İnikad Edecek Olan Büyük Kongresi Çok Müstesna Bir Ehemmiyete Haizdir." başlı̆̆ını taşırken, ${ }^{58}$ Akşam gazetesi 15

54،"Büyük Gazimizin tarihi Nutku 36 Saat 33 dakika devam Etmiştir”, Milliyet, 21 Teşrin-i Evvel 1927, s. 1.; Vakit, 21 Teşrin-i Evvel 1927, s. 1. İsmail Arar, "Büyük Nutkun Kapsamı, Niteliği, Amacı", Atatürk'ün Büyük Söylevinin 50. Yılı Semineri, s. 127; Hikmet Bila, CHP Tarihi 1919-1979, s. 81. Mustafa Kemal Paşa, 15 Ekim 1927 Cumartesi 5 saat 32 dakika, 16 Ekim 1927 Pazar günü 5 saat 37 dakika, 17 Ekim 1927 Pazartesi günü 6 saat 20 dakika, 18 Ekim 1927 Salı günü 6 saat 24 dakika, 19 Ekim 1927 Çarşamba günü 6 saat 24 dakika ve 20 Ekim 1927 Perşembe günü 6 saat 14 dakika olmak üzere Büyük nutkun tamamını 36 saat 31 dakikada okumuştur.

55 Hâkimiyet-i Milliye gazetesi 10 Ocak 1920 yılında yayınlanmaya başladı. Milli Mücadele'nin sözcüsü olan gazete, daha sonraki yıllarda Ulus adiyla yayın hayatına devam etmiştir. İzzet Öztoprak, Kurtuluş Savaşı'nda Türk Basını, s. 11-12.

${ }^{56}$ Habere göre Cumhuriyet Halk Fırkası'nın büyük kongresi öğleden önce saat onda açılacaktı. Açılış saatine kadar milletvekilleri ve vilayetlerden gelen kongre üyeleri jaketayi veyahut redingot elbise giyerek toplantıya katılacaktı. CHF Genel Baskanı Gazi Hazretleri bir nutuk ile kongreyi açtıktan sonra nizamname uyarınca kongrenin ikinci başkanı ve kâtipleri seçilerek mesai başlayacaktı. Kongrenin açılışına ait bu bilgilerden sonra nutukla ilgili haberlere geçilmiştir. Hâkimiyet-i Milliye, 15 Teşrin-i Evvel 1927, s. 1.

${ }^{57}$ Cumhuriyet, 15 Teşrin-i Evvel 1927, s. 1. Büyük Nutuk'u dinlemek için 315 milletvekili, 63 ilden gelen Halk Fırkası üyesi 2 delege dışında sefirler, askerler, bürokratlar, memurlar ve halk salonda hazır bulunmuş̧tur. "Büyük Kongre Nasıl Küşad Edildi”, Milliyet, 16 Teşrin-i Evvel 1927, s. 1.

${ }_{58}^{58}$ Haberde kongre hakkında bilgi verildikten sonra konu Büyük Nutuk'a getirilmis, “...teyide hacet yok ki, Gazi'nin nutku, gelişigüzel herhangi bir firka reisinin nutkuyla mukayese edilemez." dendikten sonra nutkun hem Cumhuriyet Halk Firkası'nın hem de Yeni 
Ekim günü verdiği kısa haberde: "Murahhaslar Toplandılar, Fırka Kongresi Yarın Saat Onda Toplaniyor, Murahhaslar Kamilen Geldiler" ifadesini kullanmıştır. ${ }^{59}$ Vakit gazetesi çerçeve içine alarak öne çıkardığı haberi "Büyük Kongre Bugün Ö̆gleden Evvel Küşad Ediliyor" sözleriyle duyurdu. ${ }^{60}$ Íkdam gazetesi ${ }^{61}$ de "Fırka Kongresi Bugün İçtimağ Edecek" adlı haberde öğleden önce fırka kongresinin açılış töreninin yapılacağını, öğleden sonra Mustafa Kemal Paşa'nın "tarihi nutku”nu okumaya başlayacağını ve bunun bir hafta süreceğini duyurmuştur. ${ }^{62}$

Yaygın basında 16 Ekim tarihinden itibaren birinci sayfa başta olmak üzere sayfalar CHF Kongresi ve nutukla ilgili haberlere ayrılmıştır. Katılımcılar, dinlemeye gelenler, salonun durumu, Mustafa Kemal Paşa'nın ne giydiği ve açılış günü meclise girişi gibi tüm yaşananlar yaygın basındaki gazetelerde benzer sözcüklerle -ama en ince ayrıntısına kadar- ifade edilmiştir. Denilebilir ki, radyo yayınının yapılmadığı bu dönemde, yaygın basın aracılığıyla gazeteleri okuyanlar Büyük Nutuk'u salonda dinlemiş gibi olacaklardır. ${ }^{63}$

İlk sayfanın tamamının kongre açılışına ve okunacak nutukla ilgili haberlere ayrıldı $\breve{g}_{1} 16$ Ekimdeki Hâkimiyet-i Milliye gazetesi "Gazi Hazretleri Fırkamızın büyük kongresini dün Millet Meclisi'nde küssad buyurdular. Vatanı kurtarmak ve yükseltmek yolundaki dokuz senelik icraat ve mesailerine dair beyanatta bulunmaya başladılar" sözleriyle konuyu manşetten vermiştir. Haberde ilk günün ayrıntılı bir özeti de bulunmaktadır. ${ }^{64}$ "Vatanı kurtaran" Mustafa Kemal Paşa, "Vatanı Kurtaranın Fırkası"nın açılıșı için alkışlar arasında salona girerken üzerinde jaketatayi vardır. ${ }^{65}$ Mustafa Kemal Paşa devam eden alkışlar arasında riyaset kürsüsüne çıkarken, Erkan-1 Harbiye Umumiye Reisi Müşir Fevzi Paşa hazretleri, Paris Büyükelçisi Fethi, Prag elçisi Vasıf Beyler, Riyaset-i Cumhur locasına, ordu müfettişi Ali Seyid, İzzettin Paşalar ve kolordu

Türkiye'nin tarihini aydınlatacak bir belge olduğu vurgulanmıştır. Milliyet, 15 Teşrin-i Evvel 1927, s. 1.

59 “Murahhaslar Toplandılar", Akşam, 15 Teşrin-i Evvel 1927, s. 1. 1927, s. 1.

00 "Büyük Kongre Bugün Öğleden Evvel Küşad Ediliyor", Vakit, 15 Teşrin-i Evvel

${ }_{61}$ İkdam gazetesi, 1894-1928 yılları arasında İstanbul'da yayınlanmıstır. İzzet Öztoprak, Kurtuluş Savaşı'nda Türk Basını, s. 5.

${ }_{22}^{2}$ "Fırka Kongresi Bugün İçtimağ Edecek", İkdam, 15 Teşrin-i Evvel 1927, s. 1.

${ }^{63}$ Mustafa Kemal Paşa'nın kongreyi açışı: “...Gazi ayakta olduğu halde elini cebine soktu ve cebinden küçük kırmızı bir defter çıkardı ve kaşlarını çattı, o küçük defterin küçücük sayfalarını karıştırdı. Önüne bıraktı..." şeklinde en ince ayrıntısına kadar aktarılmıştır. Milliyet, 16 Teşrin-i Evvel 1927, s. 1. Büyük Nutuk ve kongre ile ilgili betimleme ve haberlerde bu hikâyeci anlatım devam etmiştir.

${ }^{64}$ Hâkimiyet-i Milliye, 16 Teşrin-i Evvel 1927, s. 1.

${ }^{65}$ Gazeteler sadece nutukla ilgili değil, Mustafa Kemal Paşa'nın kıyafetlerini de okuyucularına ayrıntılı bir şekilde duyurmuştur. Örneğin 17 Ekim günü lacivert elbise giymiştir. Hâkimiyet-i Milliye, 17 Teşrin-i Evvel 1927, s. 1. 
kumandanı Şükrü Naili Paşa ve büyükelçiler Muhtar ve Memduh Şevket Beyler yan taraftaki locaya geçerler. ${ }^{66} \mathrm{Bu}$ esnada Mustafa Kemal Paşa kürsüye gelerek Cumhuriyet Halk Fırkası'nın büyük kongresini açtığını ilan etmiş; ardından kırmızı defterini çıkararak oraya işaret ettiği konu başlıklarını ancak kendisinin başaracağı bir tarz ve üslupla okumaya başlamıştır.

İlk sayfasını Büyük Nutuk ve Cumhuriyet Halk Fırkası Kongresi'ne ayıran bir diğer gazete Vakit'tir. Haberi: “Cumhuriyet Halk Firkası'nın İlk Büyük Kongresi Dün Sabah Saat Onda Büyük Millet Meclisi Salonunda Açıldı: Gazi Hazretleri Tarihimizin En Güzide Sahifelerini Teşkil Etmekte Olan Nutuklarını Irada Başladılar" sözleriyle ve çerçeve içinde veren gazete birinci sayfada konuyla ilgili iki köşe yazısı yayınlamıştır. "Büyük Nutuktan Evvel" adlı yazıda nutuk okunmadan önce yaşananlar aktarılmış; başyazar tarafından yazılan "Gazinin Eseri" adlı haberde Büyük Nutuk'la ilgili açıklamalar yapılmıştır. ${ }^{67}$

Cumhuriyet gazetesi ${ }^{68}$ başlığında: "Dün Firka Kongresi toplandı: Gazi Hazretleri Tarihi Nutuklarını Irada Başladılar" dedikten sonra diğer gazetelerde yer alan kongre açılışıyla ilgili haberleri aktararak Mustafa Kemal Paşa'nın bir vecizesine yer vermiştir. ${ }^{69}$ Ve her gün ilk sayfada Mustafa Kemal Paşa'nın sözlerini çerçeve içinde "Gazi'nin Vecizeleri" başlığıyla sunmaya devam etmiştir. ${ }^{70}$

${ }^{66}$ Hâkimiyet-i Milliye, 16 Teşrin-i Evvel 1927, s. 1. Dinleyenler arasında yabancı elçiler yanında İstanbul Darülfünun Edebiyat Fakültesi'nden Köprülüzade Fuat, Fen Fakültesi reisi Tamer Beyler ile bu dönem Ankara'da yapılan Tıp Kongresi'ne katılmak için gelen Darülfünun Emini Dr. Ömer Bey de vardır. "Darülfünun Fakülte Reisleri Ankara'da", Cumhuriyet, 16 Tessrin-i Evvel 1927, s. 1.

${ }^{67}$ Vakit, 16 Teşrin-i Evvel 1927, s. 1-2. Vakit gazetesi ikinci sayfasının tamamına yakınını Büyük Nutukla ilgili haberlere ayırmıştır. Büyük nutuk ve kongreyle ilgili fotoğraflar ise en çok bu gazetede yer almış̧ır.

Cumhuriyet gazetesi, 1918 tarihinde İstanbul'da Yeni Gün adıyla yayınlanmaya basslamıstır. İstanbul'un isgali üzerine 10 A ğustos 1920 tarihinden itibaren Ankara'da, Ankara'da Yeni Gün adıyla çıkan gazete, 7 Mayıs 1924'den sonra İstanbul'da Cumhuriyet adıyla yayınlanmıştır. Günümüzde de aynı isimle çıkmaya devam etmektedir. İzzet Öztoprak, Kurtuluş Savaşı'nda Türk Basını, s. 6.

${ }^{69}$ "Büyük Gazi ve Halaskar diyor ki: "Dögüüserek, mücadele ederek ölmek, hiç olmazsa serefli idi. Hürriyeti gasp edilen bir millet ne kadar zengin ve müreffeh olursa olsun, mütemeddin insaniyet nazarında bir uşaktan daha iyi muameleye layık değildir. Türkün şerefi, hissiyatı, büyü̈ ve yüksek kabiliyeti vardır." Cumhuriyet, 16 Teşrin-i Evvel 1927, s. 1.

${ }^{70}$ Cumhuriyet gazetesinin 16 Teşrin-i Evvel 1927 tarihindeki birinci sayfası "Ankara Kongresi” başlıklı makale ve “Gazi’nin Vecizeleri” başlıklı köşe dışında tamamıyla nutukla ilgili haber ve özetlere ayrılmıştır. 
Akşam gazetesi ${ }^{71}$ kongrenin ilk gününü "Gazi Hazretleri Bu Sabah Tam Saat Onda Büyük Kongreyi Küşad Buyurdular" sözleriyle verirken habere büyük boy bir Atatürk portresi eklemiştir. ${ }^{72}$

Yaygın basın içinde haberleri fotoğraf kullanmadan veren İkdam gazetesi 16 Ekim günü manşetten ve çerçeve içinde verdiği "Cumhuriyet Halk Fırkası Kongresi Dün Ankara'da Büyük Millet Meclisi Salonunda Topland ve Reisi Cumhur Gazi Mustafa Kemal Hazretleri Tarihi ve Mühim Nutkunu Irada Başladılar. Halk Fırkası Kongresinde, Fırkanın Müstakbel Hareket ve Ícraatına Müteallik Tedabir Dahi Müzakere Edilecek", haberinin altında Mustafa Kemal Paşa'nın nutkunda dokuz senelik dönemin tarihine değineceği belirtilerek ilk gün yaşananlar -Kongrenin başlamasından önce yaşananlar, Mustafa Kemal Paşa'nın Kongreyi açışı ve açış konuşmasından sonraki kongre ile ilgili görev dağılımı da (kongredeki alkıș sesleri de dâhil)aktarılmıştır. $^{73}$

Mustafa Kemal Paşa'nın kongrede açış konuşması yapmasına kadar geçen süreçte basın Cumhuriyet Halk Fırkası'nın ilk kongresinin toplanacağını yazmıştır. Mustafa Kemal Paşa'nın Cumhuriyet Halk Fırkası'nın dokuz sene önce ortaya çıktığını ve bu yüzden ilk kongresini Sivas'ta yaptığını ifade ederek ikinci büyük kongreyi ${ }^{74}$ açtı̆̆ını dile getirdiği konuşmasından sonra bütün gazeteler gerçekleşen kongreden İkinci Kongre diye bahsetmişlerdir. ${ }^{75}$ Büyük Nutuk'un okunduğu altı gün boyunca haberler -Refet Paşa'nın Halifeye hediye ettiği atla ilgili haber dışında ${ }^{76}$ genelde konuyla ilgili başlık atarak fotoğraflarla desteklenerek verilmiştir.

Yaygın basında Büyük Nutuk'un geniş özetleri yanında makale veya yorumlar ağırlık taşımıştır. Genel olarak Yunus Nadi, ${ }^{77}$ Yakup

${ }^{71}$ Bütün gücü ile Milli Mücadele yanında olan Akşam gazetesi, ilk sayısını 9 Mayıs 1918 tarihinde çıkarmış, uzun bir süre yayınlanmaya devam etmiştir. İzzet Öztoprak, Kurtuluş Savaşı'nda Türk Basını, s. 7.

72 "Gazi Hazretleri Bu Sabah Tam Saat Onda Büyük Kongreyi Küşad Buyurdular", Akşam Gazetesi, 16 Teşrin-i Evvel 1927, s. 1. Haberde sabah sekizden itibaren kongrenin yapılacağı alandaki yaşananlardan başlayarak Mustafa Kemal Paşa'nın kongre binasına gelişi, kongreyi açış konuşması ayrıntılı bir şekilde okuyuculara açıklanmıştır.

${ }_{73}$ I kdam, 16 Teşrin-i Evvel 1927, s. 1-2.

${ }^{74}$ Mustafa Kemal Paşa, Sivas Kongresi'ni bütün milletin istek ve düşüncelerinin temsil edildiği bir kongre olduğunu, bu ikinci kongreyle de CHF'nin bütün milletin gerçek duygu ve temennilerine tercüman olma görevini üstlendiğini dile getirdi. Kongre sonrasında kabul edilen değişmez genel başkan sıfatıyla partisinin başında bu hedeflere ulaşılmasını sağlayacak lider de kendisi olacaktı.

${ }^{75}$ Yunus Nadi, "Ankara Kongresi” adlı makalesinde Erzurum ve Sivas Kongrelerinden sonra bu kongreye Ankara Kongresi unvanının verilmesini arzuladığını dile getirse de bu görüşü yaygınlık kazanmadı. Yunus Nadi, “Ankara Kongresi”, Cumhuriyet, 16 Teşrin-i Evvel 1927, s. 1-2.

76 "Refet Paşa'nın Abdülmecid'e Hediye Ettiği At Münasebetiyle Yazılan Nameler", Vakit, 20 Teşrin-i Evvel 1927, s. 2.

${ }^{77}$ Yunus Nadi, "Ankara Kongresi”, Cumhuriyet, 16 Teşrin-i Evvel 1927, s. 1-2.; Yunus Nadi, "Erzurum ve Sivas", Cumhuriyet, 17 Teşrin-i Evvel 1927, s. 1-2.; Yunus Nadi, "Manda 
Kadri, ${ }^{78}$ A ̆gaoğlu Ahmet, ${ }^{79}$ Mehmet Asım, ${ }^{80}$ Akçuraoğlu Yusuf, ${ }^{81}$ Siirtli Mahmut, ${ }^{82}$ Necmettin Sadak, ${ }^{83}$ Ahmet Rasim, ${ }^{84}$ Zeki Mesud, ${ }^{85}$ Hakk1 Tarık, ${ }^{86}$ Aka Gündüz, ${ }^{87}$ Vasıf, ${ }^{88}$ Avram Galanti ${ }^{89}$ gibi başyazarlar veya kişiler Büyük Nutuk'u ve Mustafa Kemal Paşa'nın ülke ve Cumhuriyet rejimi için neler ifade ettiğini gün be gün en ince ayrıntısına kadar yorumlamışlardır. Hâkimiyet-i Milliye gazetesi yazarlarından Siirtli Mahmut, Yakup Kadri ve A ğaoğlu Ahmet'in makalelerinden bazıları aynı gün Milliyet gazetesinde de yayınlanmıştır. Mustafa Kemal Paşa "yaptı̆̆ nitelenirken yaptıklarıyla "tarihin tunçtan levhalarına sadece emsalsiz bir kılınç adamı, emsalsiz bir devlet başkanı sıfatıyla değil, emsalsiz bir fikir ve

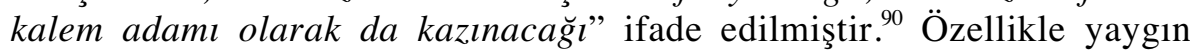

Meselesi”, Cumhuriyet, 18 Teșrin-i Evvel 1927, s. 1-2.; Yunus Nadi, "İlk Zafer", Cumhuriyet, 19 Teşrin-i Evvel 1927, s. 1-2.; Yunus Nadi, "Şek ve İman”, Cumhuriyet, 21 Teşrin-i Evvel 1927, s. 1,3.; Yunus Nadi, "Muvaffakiyetin Sırrı", Cumhuriyet, 22 Teşrin-i Evvel 1927, s. 12.; Yunus Nadi, "Gençliğin Vazifesi", Cumhuriyet, 24 Teşrin-i Evvel 1927, s. 1.

${ }^{78}$ Yakup Kadri, "Yaptı ve Yazdı", Hâkimiyet-i Milliye, 16 Teşrin-i Evvel 1927, s. 1-2.; Yakup Kadri, "Yaptı ve Yazdı", Milliyet, 16 Teşrin-i Evvel 1927, s. 1-2; Yakup Kadri, "Büyük Nutkun Faideleri”, Hâkimiyet-i Milliye, 25 Teşrin-i Evvel 1927, s. 1.; Yakup Kadri, "Büyük Nutkun Faideleri", Milliyet, 25 Teşrin-i Evvel 1927, s. 1.; Yakup Kadri, "Büyük Nutkun Faideleri 2", Hâkimiyet-i Milliye, 28 Teșrin-i Evvel 1927, s. 1.; Yakup Kadri, "Büyük Nutkun Faideleri ”, Milliyet, 30 Teşrin-i Evvel 1927, s.1.;

${ }^{79}$ Ağaoğlu Ahmet, "Gazi'nin Nutku”, Hâkimiyet-i Milliye, 17 Teşrin-i Evvel 1927, s. 1;

Ağaoğlu Ahmet, "Büyük Kongrede", Hâkimivet-i Milliye, 19 Teșrin-i Evvel 1927, s. 1.;

Ağaoğlu Ahmet, "Büyük Kongre, İki Zihniyet", Hâkimiyet-i Milliye, 21 Teşrin-i Evvel 1927, s. 1.(Bu yazı aynı isimle 21 Ekim günkü Milliyet gazetesinde de yayınlanmıştır.); Ağaoğlu Ahmet, "Büyük Kongre: Prensiplere Sadakat”, Milliyet, 19 Teşrin-i Evvel 1927, s. 1-2.

${ }^{80}$ Mehmed Asım, "Gazinin Eseri”, Vakit, 16 Teşrin-i Evvel 1927, s. 1.; Mehmed Asım "Gazi'nin Nutku", Vakit, 17 Teşrin-i Evvel 1927, s. 1-2.; Mehmed Asım "Gazinin Gözyaşları”, Vakit, 22 Teşrin-i Evvel 1927, s. 1.

${ }_{81}^{11}$ Akçuraoğlu Yusuf, "O”, Hâkimiyet-i Milliye, 23 Teşrin-i Evvel 1927, s. 1-2.;

${ }_{82}$ Mahmut, "Büyük Kongre", Hâkimiyet-i Milliye, 15 Teşrin-i Evvel 1927, s. 1. Bu makalenin tamamı 15 Ekim günkü Milliyet gazetesinde ana sayfada Mahmut Beyin ismi kullanılmaksızın manşetten çerçeve içinde verildi..; Siirtli, "Siyaset: Ulvi Bir Hitap", Hâkimiyet-i Milliye, 20 Teşrin-i Evvel 1927, s. 1.; Siirtli, "Büyük Gazi”, Hâkimiyet-i Milliye, 21 Teşrin-i Evvel 1927, s. 1.; Mahmut, "Dinledikten Sonra", Hâkimiyet-i Milliye, 22 Teşrin-i Evvel 1927, s. 1.; Siirt Mebusu Mahmut, "Gaziyi Dinlerken”, Milliyet, 16 Teşrin-i Evvel 1927, s. $1-2$.

${ }^{83}$ Necmeddin Sadak, "Tarihi Yapan Da Odur, Yazan Da”, Akşam, 17 Teşrin-i Evvel 1927, s. 1:

${ }_{84}$ Ahmet Rasim, “Ankara Mektubları: Her İki Manasıly Nutuk Tarihi”, Cumhuriyet, 22 Teşrin-i Evvel 1927, s. 3.; Ahmet Rasim, "Ankara Mektubları: Yine Nutuk Tarihiye Dair”, Cumhuriyet, 24 Tessrin-i Evvel 1927, s. 3.

${ }^{85}$ Zeki Mesud, "Büyük Nutkun Büyük Manası", Hâkimiyet-i Milliye, 21 Teşrin-i Evvel

1927, s. 2.; Zeki Mesud, "Milli Siyaset", Hâkimiyet-i Milliye, 24 Teşrin-i Evvel 1927, s. 2.

${ }^{86}$ Hakkı Tarık, "Mahmut Paşa'nın Telgrafı", Vakit, 24 Teşrin-i Evvel 1927, s. 1.

${ }^{87}$ Aka Gündüz, "Hadiseler-İntibalar: Diriltici Kuvvetin Sesi", Hâkimiyet-i Milliye, 16 Teşrin-i Evvel 1927, s. 3.

${ }^{88}$ Vasıf, "Nutuk'u Dinlerken”, Hâkimiyet-i Milliye, 19 Teşrin-i Evvel 1927, s. 2.

${ }^{89}$ Avram Galanti, Gazinin Nutku", Vakit, 24 Teşrin-i Evvel 1927, s. 2.

90 Yakup Kadri, "Yaptı ve Yazdı", Hâkimiyet-i Milliye, 16 Tesrin-i Evvel 1927, s. 1-2.;

Yakup Kadri, "Yaptı ve Yazdı", Milliyet, 16 Teşrin-i Evvel 1927, s. 1-2; Necmettin Sadak, "Tarihi Yapan da Odur, Yazan Da", Akşam, 16 Teşrin-i Evvel 1927, s. 1. 
basında Mustafa Kemal Paşa, Milli Mücadele'nin ve devamında Cumhuriyet rejiminin -gazetelerdeki ifadeyle "Yeni Türkiye"nin ${ }^{91}$ oluşmasındaki tek adamdir. $^{92}$

Makalelerde Mustafa Kemal Paşa'nın ülkeyi düşmandan kurtaran, yeni Türkiye'yi kuran, tüm yurttaşların Ata'sı kimliklerine vurgu yapılmıştır. ${ }^{93}$ Türk milletinin Atasının etrafında birleşerek kurulan Cumhuriyeti milli egemenlik esasları çerçevesinde yaşatacağına olan inanç ve düşüncelerine bağlılık sıklıkla ifade edilmiştir. ${ }^{94}$ Geçmişte yaşanan gizli ve bilinmeyen noktalar nedeniyle o güne kadar Türk tarihinin yazılamadığı, Büyük Nutuk sayesinde gölgede kalan olayların açığa çıkacağı ve belgeler ışığında tarihin yazılacağı dile getirilmiştir. ${ }^{95}$

Bazı makalelerde Başkent Ankara Kâbe, Mustafa Kemal Paşa ise üstün nitelikli bir lider ve milli bir kahraman hatta yaradan olarak nitelenir. Büyük Nutuk'un okunduğu tarihe kadar yaptıklarıyla $\mathrm{O}$ (Samsun'a çıktığı andan itibaren Heyeti Temsiliye Reisi, TBMM Reisi, Başkomutan, Cumhurbaşkanı, CHF Genel Başkanı sıfatıyla verdiği kararlarla) ne kadar uzak görüşlü ve yanılmaz kararlar verdiğini kanıtlamıştır. Bu durum gelecekte atacağı adımların doğruluğunun da güvencesidir. O olmasaydı Milli Mücadele'nin başarılması ve Cumhuriyet'in kurularak devamındaki yenileşme hareketlerinin yapılamayacağ yapılamayacă̆ı- dile getirilmiştir. ${ }^{96}$

${ }^{91}$ Mustafa Kemal Paşa, daha 1 Mart 1338 ve 1 Mart 1339 tarihli meclisi açış nutuklarında ülkenin tarihini Milli sene olarak nitelendirdi ve yeni Türkiye'nin kuruluşunu tarihe bu şekilde not düştü. Bu tarihten sonra kurulan Türkiye Cumhuriyeti genelde Yeni Türkiye şseklinde ifade edildi. Kazım Öztürk, Cumhurbaşkanlarının T. Büyük Millet Meclisini Açış Nutukları, İstanbul, 1969, s. 105, 108, 113.

${ }_{92}$ Mehmet Asım "Gazi'nin Eseri” adlı makalesinde: "Nutuk'un bugün okunan aksamı şu hakikati ispat ediyor ki, Mücahede-i Milliye hareketi tamamen Gazi'nin eseridir." Mehmet Asım, "Gazinin Eseri”", Vakit, 16 Teşrin-i Evvel 1927, s. 1.; Milliyet gazetesinin 20 Ekim günkü başlı̆̆g: "Bu Memleketi Bir Tek Baş Kurtardı: Baş Kumandan Müşir Gazi Mustafa Kemal" şeklindeydi. Milliyet, 20 Teşrin-i Evvel 1927, s. 1.; 21 Ekimdeki başlık ise: "Reisi Cumhur Hazretlerinin Bizzat Yaptıkları, Yazdıkları ve Söyledikleri Tarih Dün Bitti”, Milliyet, 21 Teşrin-i Evvel 1927, s. 1.

${ }^{93}$ Mustafa Kemal Paşa'nın ismi gazetelerde "Gazi Paşa Hazretleri”, "Ulu Gazimiz”, "Büyük Münci”, "Büyük Halaskarımız Gazi Paşa Hazretleri” gibi nitelemelerle anılmıştır.

94 “Cumhuriyet Halk Fırkası'nın İlk Kongresi Bugün Onda Millet Meclisi'nde Umumi Reis Gazi Hazretleri Tarafından Küşad olunacaktır”, Hâkimiyet-i Milliye, 15 Teşrin-i Evvel 1927, s. 1.

${ }^{95}$ Siirt Mebusu Mahmut, "Cumhuriyet Halk Fırkasının Bugün Ankara'da İnikad Edecek Olan Büyük Kongresi Çok Müstesna Bir Ehemmiyete Haizdir”, Milliyet, 15 Teşrin-i Evvel 1927, s. 1. Siirtli Mahmut konuyla ilgili “Büyük müncinin Anadolu'ya ayak bastığı günden, Ankara'da birinci TBMM'nin küşadına, BMM'nin küşadından Izmir'in istıradadına ve nihayet İzmir'in istıradadından bu güne kadar olan vekayi bütün tafsilat ve vesaikle ortaya koyacak olan bu Nutuk; inkılâp tarihimizin şimdiye kadar karanlık kalmış olan bütün köselerini hakikatin nuru ile aydınlatacaktır" demektedir.

${ }_{96}$ Cumhuriyetin ilanından sonra Mustafa Kemal Paşa ile yolları ayrılan ve onunla dargın ölen Rauf Orbay'da Mustafa Kemal Paşa'nın ölümünden sonra Kazım Karabekir, Refet Bele ve Ali Fuat Cebesoy gibi Milli Mücadele öncülerinin olduğu bir toplantıda: "Hiç 
Yaşanan tarihin en doğru bir şekilde yazıya dökülmüş hali olarak nitelenen Büyük Nutuk, hem tarihsel bir belge ${ }^{97}$ hem de edebiyat şaheseri kabul edilmiştir. Bu nedenle Büyük Nutuk okunduktan sonra -olaylar belgelerle ve canlı şahitlerle de desteklendiği için- geçmişle ilgili herhangi bir karanlık nokta kalmayacaktır. O güne kadar milletine hiçbir zaman başka parti liderleri gibi gerçekleşmeyecek vaatlerde bulunmayan, vatanı ve milleti layık olduğu yüksek mevkiye çıkarmak için sadece gerçekleştireceği şeyleri milletiyle paylaşan ve paylaşmaya da devam edeceği bilinen Mustafa Kemal Paşa'nın kişisel özellikleri zihindeki bütün şüphelerin giderilmesinin en büyük kanıtıdır. ${ }^{98}$

Makale başlıkları ve konuları genelde o gün okunan nutkun bölümleriyle ilgilidir. Erzurum ve Sivas Kongresi'nin anlatıldı ğı gün yorumlar buna ayrılmışken, ${ }^{99}$ manda sorunu veya Gençliğe Hitabenin işlendiği gün makaleler de bu konuyla ilgili yazılmıştır. Konusu Milli Mücadele'nin evreleri veya Mustafa Kemal Paşa olmayan tek Makale Necip Asım tarafından yazılmıştır. ${ }^{100}$

Mustafa Kemal Paşa, Büyük Nutuk'unu okumayı bitirdikten sonra da yazarlar Büyük Nutuk'u değerlendirmeye devam ettiler: Yakup Kadri Büyük Nutuk'u: "Sadece Türkiye Cumhuriyetinin değil aynı zamanda Cumhuriyet Halk Fırkası'nın da nereden gelip nereye gidecĕ̆inin tarihi"101 şeklinde değerlendirirken, Akçuraoğlu Yusuf, “O” adlı makalesinde Mustafa Kemal Paşa'yı görmenin, hele sesini dinlemenin büyük bir şeref olduğunu ifade ettikten sonra, "O, yalnız Türk düşmanlarına galebe çalarak, Türk yurdunu kurtarmadı: O, yalnız Türklerin önüne düşerek, Türklere dŏ̆ru yolu göstererek, Türklere hakikati göstererek Türk’leri necata erdirmedi. O, Ademoğullarının büyük bir kısmına, hatta yalnız büyük bir kısmına değil, belki hepsine yeni bir hayat yaratıyor....Yeni bir hayat yaradana bilmem ne

birimiz olmasaydık Kurtuluş Savaşı'nı Atatürk gene başarırdı. Ama o olmasaydı hiç birimiz. onun yaptığını yapamazdık" diyerek bu görüşü desteklemiştir. Aktaran: Falih Rıfkı Atay, Çankaya, Pozitif Yayınları, İstanbul, 2004, s. 69.

${ }_{97}$ Avram Galanti Büyük Nutuk'u tarihsel bir belge olarak kabul ederek tarih usullerine göre değerlendirmiştir. Avram Galanti, "Gazinin Nutku: Usul-ü Tarih Nokta-i Nazarından Kiymeti", Vakit, 24 Teşrin-i Evvel 1927, s. 2.

${ }_{98}$ Hakkimiyet-i Milliye, Cumhuriyet, Akşam, Vakit, İkdam ve Milliyet gazeteleri 16-28 Teşrin-i Evvel 1927 tarihleri arasındaki makaleler.

99 Yunus Nadi, "Erzurum ve Sivas", Cumhuriyet, 17 Teşrin-i Evvel 1927, s. 1-2.; Yunus Nadi, "Manda Meselesi”, Cumhuriyet, 18 Teşrin-i Evvel 1927, s. 1-2

${ }^{100}$ Necip Asım, "Son Sultan İle Bir Mülakat", Hâkimiyet-i Milliye, 18 Teşrin-i Evvel 1927, s. 2. Necip Asım makalesinde "Gazi Mustafa Kemal Paşa Hazretlerinin birkaç günden beri kendilerini dinleyenleri heyecanlar içinde birakan hitabelerde" adi geçen Sultan Vahideddin ile ilgili kendi karşılaşmalarını ve düşüncelerini açıklamıştır. Necip Asım olumsuz sözlerle hatırladığı padişaha bazı tarihçilerin de "Kara Sultan" ifadesini kullandıklarını yazmaktadır. 1927, s. 1.

${ }^{101}$ Yakup Kadri, "Büyük Nutkun Faideleri”, Hâkimiyet-i Milliye, 25 Teşrin-i Evvel 
derler?" diyerek yaratıcı rolü vermiştir. ${ }^{102}$ Siirtli Mahmut ise: "Cumhuriyet Türkiye'sinin tarihini sen ibda etmiştin. Onu yazan ve milletin vicdanına, izanına tevdi eden de sen oldun! Yaptığın nutuk sadece bir tarih değildir, $O$, istikbalin Türk çocuklarına milli mefkûrelerini, milli hedeflerini gösterecek

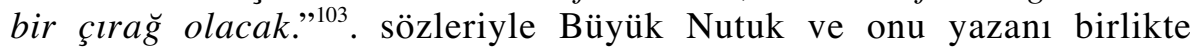
değerlendirmiştir.

Yaygın basında mutlaka yer verilen konulardan birisi de Çürüksulu Mahmut Paşa olayıdır. ${ }^{104}$ Çürüksulu Mahmud Paşa, Nutuk’ta kendisiyle ilgili geçen bölümde düzeltme yapılması ricasıyla Mustafa Kemal Paşa'ya telgraf çekmiş, bu telgrafa Mustafa Kemal Paşa yerine Cumhuriyet Halk Fırkası Genel Sekreteri: "Gazi Hazretlerinin irad buyurdukları nutuk gayrı kabil-i tereddüd esasata müsteniddir." ibaresi kullanarak karşılık vermiştir. Haber gazetelerde ayrıntılı bir biçimde işlenmiştir. ${ }^{105}$

${ }^{102}$ Akçuraoğlu Yusuf, "O”, Hâkimiyet-i Milliye, 23 Teşrin-i Evvel 1927, s. 1-2.

${ }^{103}$ Siirtli, "Siyaset: Büyük Gazi”, Hakimiyet-i Millîye, 21 Teşrin-i Evvel 1927, s. 1.

${ }^{104}$ Mustafa Kemal Paşa nutkunda: Ayan azasından Çürüksulu Mahmut Paşa, Bosfor gazetesi muharririne siyasi durum hakkında demeç vermiști. Mahmut Paşa o dönemler aynı zamanda İstihzarat-1 Sulhiye komisyonu üyesiydi. Mahmut Paşa, 31 Teşrin-i Evvel 335 tarihli Tasvir-i Efkar gazetesinde de yayınlanan demecinde Ermeniler lehine toprak tavizinde bulunulabileceğini söylüyordu. Bu demeci 17 gün sonra Sivas'ta okuduğunu dile getiren Mustafa Kemal Paşa, Çürüksulu Mahmut Paşa'ya Erzurum ve Sivas Kongresi kararları uyarınca Ermenistan'a bir karış toprak verilemeyeceğini, hükümetle ayrı düşüldüğünde milletin kendi hukukunu bizzat savunacağını dile getiren bir telgraf çekerek durumu açıklamıştı. Bunun üzerine Çürüksulu Mahmut Paşa'nın Mustafa Kemal Paşa'ya yolladığ telgraf da (vesika 197 olarak nutukta da verildi) gazetede yayınlandı. Bu telgrafta Çüruksulu Mahmut Paşa kendini şu şekilde ifade etti: "Beyoğlu 19: Vakit gazetesinde nutuk riyaset penahilerine atfen istihzarat-l sulhiye komisyonunda bulunduğum esnada gazetelere hükümetin Sarkta Ermenistan lehine tavizat-ı arziyede bulunacağını vaad ve ifade eder sözlerde bulunduğu ve zat-l devletlerinin ikaz ve tashihi mütezammın telgraf çektiklerini okudum. Müttehir oldum. Sark vilayetleri hakkında yegane beyanatım 24 Mart 1919 tarihli Istiklal gazetesinde münderic olup şekl-i hazırın tamamen veya klsmen tadili maddeten

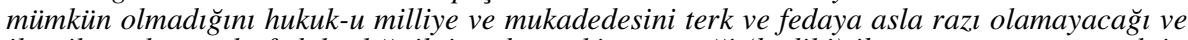
ila-nihaye her türlü fedakarlığ ihtiyardan çekinmeyece ği (bedihi) ibaratı aynen müserrehtir. Komisyona memuriyetim esnasında ne komisyon namina ve kendi namıma gazetelere beyanatta bulunduğum yoktur. Zat-ı devletlerinden de telgraf aldığımı tahatür edemiyorum. Hayat ve mesle ğim memleketimizin selameti uğrundaki mesaim ve ayandaki beyanatım isnad ve redde kafidir. Nezd-i fehimanelerinde husule geldiğini teessüfle gördüğ̈̈m bu yanlıs zehabın tashihi ricasına cüret ederek arz-ı tazimat eylerim efendim hazretleri." Kabataş, sabık-1 ayandan Çürüksulu Mahmut. "Gazi Hazretlerinin İrad Buyurdukları Nutuk Gayrı Kabil Tereddüd esasata Müsteniddir" Vakit, 23 Teşrin-i Evvel 1927, s. 1-2.; "Çürüksulu Mahmut Paşa'nın Gazi Hazretlerine Müracaatı", Cumhuriyet, 23 Teşrin-i Evvel 1927, s. 2.

105 "Mezardan Bir Ses", Hâkimiyet-i Milliye, 23 Tesrin-i Evvel 1927, s. 1,3.; Mahmud, "Çürüksulu Paşa", Hâkimiyet-i Milliye, 24 Teşrin-i Evvel 1927, s. 1. (Bu makale 24 Ekim tarihli Milliyet gazetesinde de aynen aktarılmıștır.); "Gazi Hazretlerinin İrad Buyurdukları Nutuk Gayrı Kabil Tereddüd Esasata Müsteniddir.”, Vakit, 23 Teşrin-i Evvel 1927, s. 1.; Hakkı Tarık, "Mahmut Paşanın Telgrafı", Vakit, 24 Teşrin-i Evvel 1927, s. 1.; "Çürüksulu Mahmut Paşa'nın Gazi Hazretlerine Müracaatı", Cumhuriyet, 23 Teşrin-i Evvel 19̧27, s. 2.; "Gazi Hazretlerinin Kongredeki Beyanatı Gayrı Kabil Tereddüt Esasatı Müsteniddir", Milliyet, 23 Teşrin-i Evvel 1927, s. 1. 
Yaygın basında, Büyük Nutuk'ta Mustafa Kemal Paşa tarafından eleştirilen kişilere Nutuk'ta geçen ifadelerden daha ağır ithamlarda bulunulmuştur. ${ }^{106}$ Nutuk'ta geçen olumsuz haberleri -örneğin Vakit gazetesi"Büyük Gazi'nin nutuklarında işaret edilen bazı hadiselere ait hulasalar ve meydana çıkan hakikatler" şeklinde çerçeve içinde ve başta Halide Edip Hanım olmak üzere Rauf Bey, Refet Bele, Kara Vasıf, Bekir Sami Beylerin fotoğraflarıyla birlikte haber yaparken, ${ }^{107}$ yerel basında bu konuya değinilmemiştir. Çürüksulu Mahmut Paşa dışında Nutuk okunurken yazılanlara karşı olduğunu dile getiren bir diğer isim Halide Edip Hanım'dır. Ancak onunla ilgili haber yaygın basında Hâkimiyet-i Milliye gazetesinde ele alınmıştır. $^{108}$

Mustafa Kemal Paşa, Büyük Nutuk'unu Türk ulusunun geleceği olarak gördüğü gençlere hitab ederek bitirmiştir. Gençliğe Hitabe yaygın basında genelde özel çerçeve içinde ve Mustafa Kemal Paşa'nın fotoğrafıyla verilmiştir. Bir tür vasiyetname kabul edilen bu hitabeyi okuyan Paşa "Büyük bir tarihi yapan ve yazan" kişi diye nitelenirken Gençliğe Hitabe ile Türk gençliğine bundan sonra izleyeceği hedefi gösterdiği vurgulanmıştır. ${ }^{109}$ Nutuk'un bitiminde Gazi'nin hem kendisinin hem de kongreyi dinleyenlerin

${ }^{106}$ Milliyet gazetesinin başlıktan verdiği yorum örnek verilirse: "Reisi Cumhur hazretlerinin ifşaatı tarihiyesi devam etmektedir: Ali Fuat, Refet Paşalar İsmet paşayı nasıl kıskandılar, Celalettin Arif Bey Erzurum'da meclisi yıkmak için nasil bir oyun hazırlıyordu, Yeşil Ordu nasil teşkil etti...Hele, şu Celalettin Arif Beyin Gazi'ye oyun etmeye kalkmasina ne denir?", Milliyet, 19 Teşrin-i Evvel 1927, s. 1. ; İkinci Grup içinse "fesad zümresi” ifadesi kullanıldı. "İzzet Paşa Namusu Üzerine Verdiği Sözde Niçin Durmadı", Milliyet, 20 Teşrin-i Evvel 1927, s. 1.

107 "Büyük Gazi'nin Nutuklarında İşaret Edilen Bazı Hadiselere Ait Hulasalar Ve Meydana Çıkan Hakikatler", Vakit, 16 Teşrin-i Evvel 1927, s. 2.

108 "Halide Hanımın Tahrifatı" adlı haberde: "Halide Hanım Times'da Gazi Hazretleri'nin tarihi beyanatındaki vekayi tahrife kalkıştı. Nutuk'un mündericatı ve vesaiki okununca hakiki hadisatın Halide Hanım'ın verdi ği gibi olmadığ g görülecektir. 21 Teşrin-i Evvel 1927 tarihli Times'da Halide Hanım Gazi Hazretlerinin nutku münasebetiyle vakays tahrif eder tarzda beyanatı görülmüs ve bu mesele hakkında Londra'da Times gazetesi müdiriyetine atideki cevap verilmiştir: "Doktor Adnan Bey'in zevcesi Halide Edib Hanım 21 Tesrin-i Evvel 927 tarihli Times'da intisar eden mektubu görülmüstür. Hakiki hadisatın cereyanı Halide Hanım'in mektubunda tahattür ve zikr ettiklerine asla tevafuk etmediğini nutkun mündericatı ve vesaiki aynen okunduğ zaman anlaşlacağını ve kendilerine de hakiki hadisatı tahattür ettireceğini ümid ederim." sözleriyle verilmiştir. "Halide Hanımın Tahrifatı", Hâkimiyet-i Milliye, 29 Teşrin-i Evvel 1927, s. 1.

109 "Tarihi Nutkun Sonrasında Gazi Hazretlerinin Gençliğe Hitabesi”, Hâkimiyet-i Milliye, 21 Teşrin-i Evvel 1927, s. 1.; "Gazi Türk Gençliğine Hedefini Gösterdi”, Milliyet, 23 Teşrin-i Evvel 1927, s. 1. ; "Gençliğin Yemini”, Milliyet, 24 Teşrin-i Evvel 1927, s. 1; "Büyük Bir Tarihi Yapan ve Yazan Gazi’nin Türk Gençliğine Ulvi Hitabeleri”, Vakit, 21 Teşrin-i Evvel 1927, s. 1.; "Gazi Hazretleri, Gençliğe Hitaben İrad Buyurdukları Ulvi Bir Hitabeyle Nutuklarına Nihayet Verdiler", Vakit, 21 Teşrin-i Evvel 1927, s. 2.; "Gazi Hazretleri Bugün Tarihi Nutuklarını İkmal Buyurdular: Gazi Türk Gençliğine Hitaben Dedi ki”, Akşam, 21 Teşrin-i Evvel 1927, s. 1.; "Gazinin Türk Gençliğine Hitabesi”, İkdam, 21 Teşrin-i Evvel 1927, s. 1. 
ağladı ̆̆ı ayrıca belirtilir. ${ }^{110}$ Hatta Vakit gazetesinde "Gazi'nin Gözyaşları" adıyla makale yazılmıştır. ${ }^{111}$ Gençliğe Hitabenin sonrasında hem Ankara Hukuk Fakültesi öğrencileri ${ }^{112}$ hem de Darülfünun öğrencilerinin Mustafa Kemal Paşa'ya yanıtı gazetelere tüm ayrıntısıyla ve fotoğraflar eşliğinde yansıtılmıştır. ${ }^{113}$ İstanbul Belediyesi'nin Büyük Nutuk'u mermer levhalara kazıtarak şehrin değişik yerlerine koyması haberiyle Maarif Vekâleti'nin Büyük Nutuk'un Gençliğe Hitabe kısmını okullara asma kararı gazetelerin

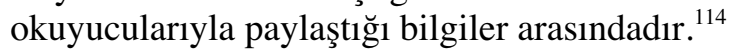

Büyük Nutuk'un okunmasının ardından çıkan haberlerden birisi de, Mustafa Kemal Paşa'nın mal varlığının büyük bir kısmını partiye bağışlamasıyla ilgilidir. 19 Ekim günkü oturumda Mustafa Kemal Paşa Büyük Taarruz'dan bahsederken metin dişı olarak dokuz seneden beri kendisine isimleri belli olan ve olmayan kişilerce yatırılan paranın da hesabını verdikten sonra, başta Çankaya'daki ev olmak üzere Bursa,

110 "Gazinin Nutkunun Husule Getirdiği Heyecan Devam Ediyor", Akşam, 23 Teşrin-i Evvel 1927, s. 1.; Milliyet gazetesi "Ey Türk Gençliği, Türk Gençliğine Hitab", başlığıyla ve çerçeve içinde verdiği haberde durumu: "Büyük Gazimizin Tarihi Nutku 36 saat 33 dakika devam etmişstir. Nutkun sonlarına doğru dahi reisimizin sesi kısılmıştı. Cebinden çıkardı ğ mendil ile gözlerinin yaşını sildi: herkes a ğlıyordu." sözleriyle okuyucularıyla paylaştı. Milliyet, 21 Teşrin-i Evvel 1927, s. 1, 3. Akşam gazetesinde Bilal imzasıyla çıkan haberde de durum: “...Gazinin senelerden beri yanında bulunmus olanlar, kendisinin ilk defa nutuk söylerken ağladı ğını görmüşlerdir" sözleriyle betimlenmiștir. Bilal, "Gazinin Nutkunun Husule Getirdiği Heyecan Devam Ediyor”, Akşam, 23 Teşrin-i Evvel 1927, s. 1.

${ }^{111}$ Mehmed Asım, "Gazinin Gözyaşları", Vakit, 22 Teşrin-i Evvel 1927, s. 1. Mehmet Asım Mustafa Kemal Paşa'nın ağlama sebebini: "Gazi nutkun son cümlesini okurken niçin ă̆llyordu? Niçin heyecanını zabt edemiyordu? ...Hiç şüphesiz Gazi yarınki Türk gençliğine düsen vazifenin ağırlığını düsü̈nerek ağlıyordu. Ve bu vazifenin a ğırlığını dokuz sene içinde görüp geçirdiğimiz acl tecrübelerle klyas ederek ölçüyordu. Yarınki Türk gençliğinin tahammül etmesi icab eden fedakârliğın derecesi gözünün önünde tecessüm ettikçe gözyaşlarını tutamamıştı." sözleriyle açıklamıştır.

"Gazinin Hitabesi ve Gençlik: Hukuk Fakültesinde Heyecanlı Tezahürat" Hâkimiyet-i Milliye, 23 Teşrin-i Evvel 1927, s. 1.21 Ekim 1927 günü Ankara Hukuk Mektebi öğrencileri, saat 13 'de toplanarak Gençliğe Hitabeyi okuduktan sonra basın açıklaması yapmışlardır. Açıklama metni için bkz: Afet İnan, Atatürk Hakkında Hatıralar ve Belgeler, s. 448.

113 “Gazimizin Hitabesi ve Gençlik”, Hâkimiyet-i Milliye, 23 Teşrin-i Evvel 1927, s. 1.; "Gazinin Hitabesi ve Gençliğin Hassasiyeti: Bugün Darülfünun Konferans Salonunda Bir İçtima Yapılacak", Cumhuriyet, 23 Teşrin-i Evvel 1927, s. 1, 3. "Darülfünun Gençliği Muazzam Tezahüratta Bulundu", Cumhuriyet, 24 Teşrin-i Evvel 1927, s. 1. 2.; "Gençliğgin Vazifesi", Cumhuriyet, 24 Teşrin-i Evvel 1927, s. 1.; "Darülfünunda", Vakit, 23 Teşrin-i Evvel 1927, s. 2.; "Gençler Dün Asil ve Heyecanlı Tezahürat yaptılar", Vakit, 24 Teşrin-i Evvel 1927, s. 1,3. "Darülfünun'da İçtima”, Akşam, 23 Teşrin-i Evvel 1927, s. 1.; "Darülfünun Gençliği Bu Sabah Muazzam ve Heyecanlı Bir İçtima Akdettiler", Akşam, 24 Teşrin-i Evvel 1927, s. 1.; "Gazi Türk Gençliğine Hedefini Gösterdi”, Milliyet, 23 Teşrin-i Evvel 1927, s. 1.; "Gençler Bugün Darülfünun'da Toplandılar", İkdam, 23 Teşrin-i Evvel 1927, s. 1.; "Darülfünun Gençliğinin Dünkü İçtimağı", Íkdam, 24 Teşrin-i Evvel 1927, s. 1.; "Büyük Gazi'nin Türk Gençliğine İltifatları", Milliyet, 30 Teşrin-i Evvel 1927, s. 1.

114 "Şehre Levhalar Talik Edilecektir", Milliyet, 27 Teşrin-i Evvel 1927, s. 1.

"Gazimizin Hitabesi ve Gençlik", Hâkimiyet-i Milliye, 23 Teşrin-i Evvel 1927, s. 1.;

“Gençliğe Hitab”, Akşam, 23 Teşrin-i Evvel 1927, s. 1.; "Gazinin Bazı Vecizeleri Heykelin Kaidesine Konacak”, Akşam, 25 Teşrin-i Evvel 1927, s. 1. 
Trabzon, Erzurum, Antalya, Konya ve İzmir'de kendisine hediye edilmiş evlerle, Ankara'da satın aldığ 1 bir kısım araziyi Cumhuriyet Halk Partisi'ne bağışlamıştı. Bu haber yaygın basında genelde çerçeve içine alınarak okuyucularla paylaşılmıştır. ${ }^{115}$

Mustafa Kemal Paşa, Büyük Nutuk'u Gençliğe Hitabe ile bitirdikten sonra salonda müthiş bir heyecan yaşanmış, dakikalarca süren alkışın ardından -ve ağlama seslerinin- Necip Asım Bey kürsüye gelerek yazdıklarını okumak istemiş ancak heyecandan başarılı olamamış, salonun "Ruşen Eşrefe" diye seslenmesi üzerine yazılanları Ruşen Eşref okumuştur. Ruşen Eşref Bey'in okuduğu Necip Asım Bey'in önergesinde "Gazi”nin Nutuk'unun kongre tarafindan teşekkür ve minnetle tasvip edilmesi" ve "firka defterine geçirilecek olan iş bu tasvip kararının kongreye iştirak eden bilumum murahhaslar tarafindan imzalanmasını ve Gazi'ye takdimi" teklif edilmiş ve bu teklif kongredeki delegelerin oybirliğiyle verdiği kararla Nutuk'ta anlatılanlar tamamen ve harfiyen onaylanmış ve millet namına tüm üyeler tarafından imzalanarak kendisine teşekkür edilmiştir. ${ }^{116} \mathrm{Bu}$ haber basın aracılığıyla kamuoyuyla paylaşılmıştır.

Büyük Nutuk okunduktan sonra da basında haberler devam etmiştir. Özellikle Gençliğe Hitabe bölümü toplumda büyük heyecan uyandırmış; başta Türk Ocakları şubeleri olmak üzere, Konya Telgrafçıları, İstanbul Kabzımalları, Eskişehir Sporcular Takımı, Halk Fırkası, Himaye-i Etfal ve Hilali Ahmer Cemiyeti başta olmak üzere, yurdun her yerinden, çeşitli sivil toplum örgütleri ve kurumlarla vatandaşlardan Mustafa Kemal Paşa'ya bağlılıklarını dile getiren telgraf ve mektuplar yollanmıştır. Hâkimiyet-i Milliye gazetesi bu haberleri sayfasında ayrıntılı bir şekilde ve çerçeve içinde yer verirken ${ }^{117}$ diğer gazeteler özetleyerek aktarmışlardır. ${ }^{118}$

115 "Büyük Gazi Cumhuriyet Halk Fırkası'nın Vatani Mesaisine Olan İtimatlarını Yeniden Teyid Buyurdular", Hâkimiyet-i Milliye, 21 Tesrin-i Evvel 1927, s. 1.; "Gazi Hazretleri Emlakini Fırkaya Verdi", Vakit, 21 Teşrin-i Evvel 1927, s. 1. ; "Gazi Hazretleri Kendilerine Ait Olan Bütün Emvali Fırkaya Bă̆ış Buyurdular", Milliyet, 21 Teşrin-i Evvel 1927, s. 2.; "Ulvi Bir Feragat: Hepsi Fırkamındır", Cumhuriyet, 21 Teşrin-i Evvel 1927, s. 1.;

“Gazi Hazretleri Mal Mülkünü ve Servetini Fırkalarına Hediye Buyurdular”, İkdam, 21 Teşrin-i Evvel 1927, s. 1.

116 “Büyük Bir Tarihi Yapan ve Yazan Gazi’nin Türk Gençliği’ne Ulvi Hitabları”, Vakit, 21 Teşrin-i Evvel 1927, s. 1.

117 "Gazimizin Gençliğe Hitabı Vatanın Her Tarafında Pek Yüksek Bir Heyecan Uyandırdı", Hâkimiyet-i Milliye, 24 Teşrin-i Evvel 1927, s. 1, 3.; "Gazimizin Hitabesi ve Gençliğin Hissiyatı", Hâkimiyet-i Milliye, 25 Teşrin-i Evvel 1927, s. 1-2.; "Gazimizin Hitabesi ve Gençliğin Hissiyatı", Hâkimiyet-i Milliye, 26 Teşrin-i Evvel 1927, s. 1-2.; "Gazimizin Hitabesi ve Gençliğin Hissiyatı", Hâkimiyet-i Milliye, 27 Teşrin-i Evvel 1927, s. 1-2.; "Gazimizin Hitabesi ve Gençliğin Hissiyatı", Hâkimiyet-i Milliye, 28 Teşrin-i Evvel 1927, s. 1-2.; "Gazimizin Hitabesi ve Gençliğin Hissiyatı", Hâkimiyet-i Milliye, 29 Teşrin-i Evvel 1927, s. 1-2.; "Gazimizin Hitabesi ve Gençliğin Hissiyatı", Hâkimiyet-i Milliye, 30 Tessrin-i Evvel 1927, s. 1.; "Gazimizin Hitabesi ve Gençliğin Hissiyatı", Hâkimiyet-i Milliye, 1 Teşrin-i Sani 1927, s. 1-2.; "Gazimizin Hitabesi ve Gençliğin Hissiyatı", Hâkimiyet-i Milliye, 2 Teşrin-i Sani 1927, s. 1-2.; "Gazimizin Hitabesi ve Gençliğin Hissiyatı", 
Büyük Nutuk sonrasında yurt dışındaki yansımaları ${ }^{119}$-nutkun uzunluğunun dünyaca ünlü nutuklarla kıyaslanması başta olmak üzere yurtdışındaki basının yorumları- yaygın basının tamamına yakınında haber olarak verilmiştir. ${ }^{120}$ Nutuk'un yabancı basındaki etkilerinden bahsedilen yazıda Türkiye'de ne zaman basılacağına dair haberler de "Nutuk ne zaman tab edilecek" alt başlığıyla ele alınmıştır. Buna göre, Tayyare Cemiyeti Piyango Müdüriyeti tarafından dört ay içinde basılacak, lüks baskıları da yapılacakt1. ${ }^{121}$

Büyük Nutuk okunurken gazetelerde Mustafa Kemal Paşa ile ilgili farklı konularda haberler de verilmiştir. Bu dönemde basında Ankara başta olmak üzere yurdun değişik yerlerine dikilecek Gazi heykelleri ile ilgili bilgiler yer alırken, ${ }^{122}$ Hâkimiyet-i Milliye gazetesi 15 Ekim günü Mustafa Kemal Paşa'nın daha önce Cumhuriyet gazetesinde tefrika edilen ama yazılmayan eserini "Pedagoji Önünde Gazi" adıyla yayınlamaya başlamıştır. ${ }^{123}$ Mustafa Kemal Paşa'nın Ankara milletvekili seçildiğine dair mazbata'nın Teftiş Heyetince hazırlanıp ciltlenerek kendilerine sunulacağ da Büyük Nutuk'un okunduğu günlerde gazetelerin birinci sayfasında okuyuculara duyurulmuştur. ${ }^{124}$

Hâkimiyet-i Milliye, 3 Teşrin-i Sani 1927, s. 1-2.; "Gazimizin Hitabesi ve Gençliğin Hissiyatı”, Hâkimiyet-i Milliye, 4 Teşrin-i Sani 1927, s. 1-2.

${ }_{118}$ Milliyet gazetesi birinci sayfada İstanbul Matbuat Cemiyeti'nin telgrafi ve Gazi Mustafa Kemal Paşa'nın yanıtını haber verdi. "Büyük Gazimizin Türk Gazetecilerine İltifatı", Milliyet, 30 Teşrin-i Evvel 1927, s. 1. Aynı gün sayfa 2'de ise Gençliğe hitap sonrasında teşekkür telgrafları yollayan diğer kuruluşlara yazdığı cevaplar yayınlandı. "Gazinin Hitabesi”, Milliyet, 30 Teşrin-i Evvel 1927, s. 2.

119 İngiltere, Fransa, Avusturya, Bulgaristan, İspanya ve Japonya'daki gazetelerde büyük nutukla ilgili haberler yer alırken, Türkiye'de bulunan bazı ülkelerin elçileri konuyla ilgili raporlar hazırladı. Bilâl N. Simșir, Atatürk’ün Büyük Söylevi Üzerine Belgeler, Ankara, 1991; Hakan Uzun, Atatürk'ün Nutuk'unun İçerik Analizi, Hacettepe Üniversitesi Atatürk İlkeleri ve İnkılap Tarihi Enstitüsü, Yayınlanmamış Doktora Tezi, Ankara, 2005, s. 37-45.

${ }_{120}$ "Tayms Gazetesi De Gazimizin Dehasına Ve Kudreti Beyanına Hayran!", Cumhuriyet, 26 Teşrin-i Evvel 1927, s. 1; "Gazinin Nutku”, Milliyet, 26 Teşrin-i Evvel 1927, s. 1-2; "Tarihi Nutuk Avrupa Matbuatı Tarafından Pek Büyük Bir Ehemmiyetle Karşılandı", Milliyet, 27 Teşrin-i Evvel 1927, s. 3.; "Reisicumhur Hazretlerinin Nutukları Hakkında İngiliz Gazeteleri Neler Söylediler”, Vakit, 26 Teşrin-i Evvel 1927, s. 1.; “Avrupa'da İlk Defa "Nöye Fraye Pres" Neşretti”, Akşam, 23 Teşrin-i Ėvvel 1927, s. 1.

121 "Reisicumhur Hazretlerinin Nutukları Hakkında İngiliz Gazeteleri Neler Söylediler", Vakit, 26 Teşrin-i Evvel 1927, s. 1.

122 "Gazimizin Heykelleri”, Hâkimiyet-i Milliye, 17 Teşrin-i Evvel 1927, s. 1.; "Büyük Gazinin Heykelleri", Hâkimiyet-i Milliye, 18 Teşrin-i Evvel 1927, s. 2.; "Büyük Gazimizin Heykelleri Ne Zaman Küşad Edilecek", Hâkimiyet-i Milliye, 27 Teşrin-i Evvel 1927, s. 1.; "Gazimizin Heykelleri Cumaya Küşad Edilecektir", Hâkimiyet-i Milliye, 1 Teşrin-i Sani 1927, s. 1.; "Gazi Hazretlerinin Heykelleri”, Cumhuriyet, 22 Teşrin-i Evvel 1927, s. 2.; "Gazinin Heykeli", Cumhuriyet, 27 Teşrin-i Evvel 1927, s. 1.; "Gazinin Heykeli", Milliyet, 27 Teşrin-i Evvel 1927, s. 1.; "Heykeltıraş Kanonika Geldi”, Akşam, 27 Teşrin-i Evvel 1927, s. 1 .

123 “Pedagoji Önünde Gazi”, Hâkimiyet-i Milliye, 15 Teşrin-i Evvel 1927, s. 2.

124 “Büyük Gazimizin İntihab Mazbatası", Hâkimiyet-i Milliye, 20 Teşrin-i Evvel 1927, s. 1 . 


\section{Yerel Basında Büyük Nutuk}

Yerel basına bakıldığında günlük yayınlanan gazete sayısı sınırlı olduğundan -taşrada gazeteler genelde haftalık, diğerleri haftada iki kez yayınlanıyordu- Büyük Nutuk'la ilgili haberlere hemen hemen her gazetede yer verilmesine rağmen, yaygın basına oranla özetlenerek sunulmuştur.

Yaygın basında Büyük Nutuk okunurken Mustafa Kemal Paşa'nın kongreye gelişi, giydiği kıyafetleri, Nutuk'u okuduğu andaki duyguları ve dinleyicilerin tepkileri başta olmak üzere tüm gelişmeler en ince ayrıntısına kadar okuyucularıyla paylaşılmıştır. ${ }^{125}$ Yerel basında ise yaygın basındaki kadar geniş olmamakla birlikte kongre açılışında ilk gün yaşananlar ve devamında nutuk özetleri aktarılmıștır. Sinop gazetesinde ${ }^{126}$ kongrenin açılışında yaşananlardan sonra Büyük Nutuk'un özeti verilirken, ${ }^{127}$ Bartın gazetesi 24 Ekim günkü sayısını tamamıla Büyük Nutuk'a ayırmıştır. ${ }^{128}$ Açıksöz gazetesi ${ }^{129}$ CHF kongresiyle ilgili haberi "Cumhuriyet Halk Firkast Bugün Saat Onda Küşad Edildi" şeklinde duyururken, aynı sayfadaki "Tarihi Nutuk" başlığıyla verilen haberde de kongre ve Büyük Nutuk'la ilgili bilgiler yer almıştır. ${ }^{130} 16$ Ekim günkü Açıksöz gazetesinde birinci sayfa tamamıyla nutukla ilgili haberler verilmiş, başlıklar çerçeve içinde özel bir şekilde sunulmuştur. Sayfanın yarısı "Reisi Cumhur Hazretlerinin Kongrede İrad Buyurdukları Küşad Nutku"na ${ }^{131}$ diğer yarısı da "Reisi Cumhur Hazretlerinin Kongrede Irad Buyurdukları Tarihi Nutkun Hulasası"

125 "Nutkun En Heyecanlı Parçaları: Gazi'nin Metris Tepede İsmet Paşa'ya Yazdığı Telgraflar Gözyaşları İçinde Dinlendi”, Akşam, 20 Teşrin-i Evvel 1927, s. 1.

${ }^{126}$ Sinop Gazetesi Sinop Vilayetinin Resmi Gazetesidir. Pazartesi ve Perșembe günleri yayınlanmıştır. 17 Ekim 1927 günü yıl: 6 sayı: 487'dir. Sinop gazetesinin kütüphanelerde sadece 17, 24 ve 27 Ekim tarihli sayıları mevcuttu.

27 "Reisi Cumhur Hazretlerinin Halk Fırkası Kongresi'nde İrad Buyurdukları Nutuk", Sinop Gazetesi, 17 Teşrin-i Evvel 1927, s. 1. "Reisi Cumhur Hazretlerinin Halk Fırkasi Kongresi'nde İrad Buyurdukları Nutuk Iftitahı”, Sinop Gazetesi, 17 Teşrin-i Evvel 1927, s. 1.; "Reisicumhur Gazi Paşa Hazretlerinin Tarihi Nutku", Sinop Gazetesi, 24 ve 27 Teşrin-i Evvel 1927, s. 1.Nutuk özetleri 20, 24 ve 27 Ekim günleri de verilmiş, devam edecektir ibaresi yer almasına rağmen sonraki sayıya kütüphanelerde ulaşılamamıştır.

${ }^{128}$ Bartın Gazetesi, Iktisadi, Içtimai, Edebi, Haftalık Memleket Gazetesi, Pazartesi günleri çıkar. 24 Teşrin-i Evvel 1927. Yıl: 3, sayı: 169. 1924-1928 yılları arası sayıları mevcut.

${ }^{129}$ Açıksöz, Müstakil Fikirli Gazete, Cuma hariç her gün yayınlanır, 15 Teşrin-i Evvel 1927 günü yıl: 9, sayı: 2071. 22 Haziran 1335 (1919) da Kastamonu'da yayınlanmaya başlayan gazete, bazı aksaklıklara rağmen 1932 yılına kadar yayınlanmıştır. 1937 yılından sonra da Doğru Söz adıyla yayınlanmaya devam etmiştir. İzzet Öztoprak, Kurtuluş Savaşı'nda Türk Basını, s. 10-11.

130 "Cumhuriyet Halk Firkası Bugün Saat Onda Küşad Edildi”, Açıksöz Gazetesi, 15 Teşrin-i Evvel 1927, s. 1.; "Tarihi Nutuk", Açıssöz Gazetesi, 15 Tessrin-i Evvel 1927, s. 1.

131 "Reisi Cumhur Hazretlerinin Kongrede İrad Buyurdukları Küşad Nutku”, Açısöz Gazetesi, 16 Teşrin-i Evvel 1927, s. 1.; "Reisi Cumhur Hazretlerinin Kongrede İrad Buyurdukları Tarihi Nutkun Hulasası", 16 Tessrin-i Evvel 1927, s. 1. "Reisi Cumhur Hazretlerinin Kongrede İrad Buyurdukları Küşad Nutku” başlıklı haber Anadolu Ajansından alındığ 1 için Sinop gazetesindeki verilen açış nutku burada da tekrar etti. 
başlığına ayrılmıştı. Mustafa Kemal Paşa'nın Nutuk'unun özeti kaldığı yerden 22 Ekim 1927 günü de verilmeye devam etmiştir. ${ }^{132}$

Bu dönemde İzmir'de yayınlanan Ahenk ${ }^{133}$ ve Hizmet gazetelerinin de sayfalarında CHF Kongresi ve Mustafa Kemal Paşa'nın okuduğu Büyük Nutuk'a geniş yer ayırdığı görülmüşsür. ${ }^{134}$

Ahenk gazetesi haberi "Fırka Kongresi Bugün Açılıyor ve Tarihi Nutuk Başliyor" sözleriyle birinci sayfadan duyurmuştur. ${ }^{135}$ Üçüncü sayfada ise Kongre ve Mustafa Kemal Paşa'nın okuyacağı Nutuk'un Anadolu Ajansı tarafından tüm gazetelere dağıtıldığı ancak ilk gün bilgilerin gazete basıldıktan sonra ellerine ulaştı̆̆ı için ertesi gün yayınlayacaklarını duyurmuştur. ${ }^{136} \mathrm{Bu}$ haberin yanında çerçeve içinde Gazi'nin Nutuk'unun ertesi günkü Hizmet gazetesinde yer alacağı da belirtilmiştir. ${ }^{137}$

Ahenk gazetesi 16 Ekim tarihinden itibaren kongre açılışı ve Büyük Nutuk'la ilgili haberleri tıpkı yaygın basındaki gibi-dinleyicilerin alkış sesleri de dahil- ayrıntılı bir şekilde okuyucularla paylaşılmış, haberler çerçeve içine alınarak birinci sayfadan sunulmuştur. ${ }^{138}$ Büyük Nutuk'la ilgili haberler ve özetler ilk gün "Büyük Halaskarımız, Bütün Milletin Beklediği Büyük Nutuklarını Írada Başlamışlardır" sözleriyle verilmiş, devam eden günlerde ise başlık "Büyük Halaskarımız, Bütün Milletin Beklediği Büyük Nutuklarını Irad Buyurmaktadırlar" şeklinde ifade edilmiştir. Büyük Nutuk'un bittiği ise "Büyük Gazimizin Millete En Büyük Hediyelerinden Biri Olan Nutukları Hitam Buldu" sözleriyle duyurulmuştur.

Hizmet gazetesi, ${ }^{139} 14$ Ekim sayısında çerçeve içine aldığ 1 "Gazi Hazretlerinin Tarihi Nutku" haberde okuyucularına cumartesi günü

132 "Reisi Cumhur Hazretlerinin Kongrede İrad Buyurdukları Tarihi Nutkun Hulasası", Açıksöz, 17-18-19-20-21-22 Teşrin-i Evvel 1927, s. 1-2.

${ }_{133}$ Ahenk, 1312, Y1l: 33, Say1: 10262, İzmir.

${ }_{134}$ İncelenen dönemde İzmir'de yayınlanan Yeni Asır gazetesinin 15-30 Ekim 1927 tarihleri arasındaki sayılarına İzmir, Ankara ve İstanbul'daki kütüphanelerde ulaşılamamıştır. Anadolu gazetesinin nüshaları İzmir Milli Kütüphanede bulunmakla birlikte cilde gönderildiğinden dolayı yararlanılamamıştır.

${ }^{135}$ Haber okuyuculara "Halk Firkası Kongresi, bugün Büyük gazi Mustafa Kemal Hazretleri tarafindan merasim-i mahsusa ile küssad edilecektir. Gazimiz küşad nutkunu bizzat irad edeceklerdir. Nutkun hitamını müteakib ikinci reis ve katibi umumi intihabatı başlayacak, ruzname müzakere olunacak ve Gazimizin tarihi nutku başlayacaktır.” Sözleriyle duyurulmuştur. Büyük Nutul ile ilgili ayrıntılı haberler 16 Ekim tarihinden itibaren sunulmuştur. "Fırka Kongresi", Ahenk, 15 Teşrin-i Evvel 1927, s. 1.

${ }_{136}$ "Büyük Gazimiz Tarihi Nutuklarını Bugün Öğleden Sonra Okumaya Başlamışlardır", Ahenk, 15 Teşrin-i Evvel 1927, s. 3

${ }_{137}^{137}$ "Gazinin Nutku yarinki Hizmet refikimizde mevcuddur. Okuyunuz.", Ahenk, 15 Teşrin-i Evvel 1927, s. 3.

138 "Büyük Halaskarımız, Bütün Milletin Beklediği Büyük Nutuklarını İrada Başlamışlardır". Ahenk, 16 Teşrin-i Evvel 1927, s. 1; "Büyük Gazimizin Tarihi Nutukları”, Ahenk, 16 Teşrin-i Evvel 1927, s. 2.

${ }^{139}$ Hizmet Gazetesi, Cumartesinden maada her gün çıkar milliyetçi, cumhuriyetçi, Türk gazetesidir. Sene: 41 , numara: 847 . 
kongrenin başladığı ve Mustafa Kemal Paşa'nın da Büyük Nutuk'unu okuduğu takdirde Pazar gününden itibaren geniş özetinin ve ayrıntılı bilgilerin verileceğini duyurmuştur. ${ }^{140}$ Cumartesi günleri gazete çıkmadı̆̆ için nutukla ilgili haberlere 16 Ekim 1927 tarihinden itibaren verilmiştir. ${ }^{141}$ İlk gün kongre açılışında yaşananlar, Mustafa Kemal Paşa'nın Kongreyi açış nutku da dahil okuyucularla paylaşılmıs, sayfanın tam ortasına ise diğer gazetelerde olmayan bir köşe yapılmış ve o gün okunan Nutuk'un kısa bir özetini çerçeve içine alarak sunmuştur. ${ }^{142}$ Mustafa Kemal Paşa'nın Büyük Nutuk'u okuduğu günler boyunca gazete nutukla ilgili haberleri ve özetleri vermeye devam etmiştir. ${ }^{143}$

Kütüphanelerde tüm nüshalarına ulaşılamayan Babalık gazetesi ${ }^{144} 20$ Ekim 1927 tarihli sayısının ilk sayfasını tamamen Büyük Nutuk'a ayırmıştır. Başlık: "Gazi Hazretleri Milli Mücadelenin Vakayı Siyasiye Ve Askeriyesini Teşrihde Devam Ediyorlar." şeklindedir. Bu yazıda Mustafa Kemal Paşa'nın mecliste o gün yaptığı konuşmanın geniş bir özeti verilmiştir. ${ }^{145}$

Balıkesir gazetesinin ${ }^{146} 17$ Ekim tarihli haberinden biri "Halk Fırkası Kongresi” başlı̆̆ını taşıyordu. Cumhuriyet Halk Fırkası'nın büyük kongresinde Mustafa Kemal Paşa tarafından okunacak Büyük Nutuk'un özetini vererek yetinecekleri belirtildi. Bu yazılanların tekrar tekrar okunarak feyz ve ilham alınacağı da eklendi. ${ }^{147}$ Sayfanın dörtte biri bu habere geriye kalan dörtte üçü "Gazi Hazretlerinin Irad Buyurdukları Muazzam ve Tarihi Nutuk" başlıklı yazıya ayrıldı. Yazının altında bir de kısa cümle yer aldı: "İlk irad buyurulan nutkun hulasasıdır". Bu açıklamadan sonra Açıksöz ve Babalık gazetelerinde de benzer şekilde verilen Nutuk özetine geçildi. Yine

\footnotetext{
140 “Gazi Hazretlerinin Tarihi Nutku”, Hizmet, 14 Teşrin-i Evvel 1927, s. 1.

141 “Gazi Mustafa Kemal Hazretleri Tarihi Nutuklarını Dün İrada Başladılar”, Hizmet, 16 Teşrin-i Evvel 1927, s. 1-2.; "Büyük Gazi Dün Neler Söyledi”, Hizmet, 16 Teşrin-i Evvel 1927, s. 3 .

142 "Tarihi Nutkun Kısa Bir Hulasası", Hizmet, 16 Tessrin-i Evvel 1927, s. 1.
143 "Gazi Mustafa Kemal Hazretlerinin Tarihi Nutukları", Hizmet, 17 Teşrin-i Evvel 1927, s. 1.; "Büyük Gazimiz Tarihi ve Muazzam Nutuklarının İradına Dün de Devam Buyurdular", Hizmet, 18 Teşrin-i Evvel 1927, s. 1. ; "Büyük gazimizin Tarihi Nutukları", Hizmet, 18 Teşrin-i Evvel 1927, s. 2.; "Gazi Mustafa Kemal Hazretleri Tarihi ve Muazzam Nutuklarına Dün de devam Buyurdular", Hizmet, 19 Teşrin-i Evvel 1927, s. 1. ; "Gazi Mustafa Kemal Hazretleri Tarihi ve Muazzam Nutuklarına dün de devam Buyurdular", Hizmet, 20 Teşrin-i Evvel 1927, s. 1. ; "Gazi Mustafa Kemal Hazretleri Tarihi ve Muazzam Nutuklarına Dün de Devam Buyurdular”, Hizmet, 21 Teşrin-i Evvel 1927, s. 1. ;

${ }_{144}$ Babalık Her Gün Neşrolunur Türk Gazetesidir, 24 Teşrin-i Evvel 1927 günü yıl: 17, sayı: 2523. 1910-1929 yılları arasında Konya'da yayınlanmıştır. 29 Aralık 1910- 1951 tarihleri arasında yayınlanmıştır. İzzet Öztoprak, Kurtuluş Savaşı'nda Türk Basını, s. 9.

145 "Gazi Hazretleri Milli Mücadelenin Vekayi-i Siyasiye ve Askeriyesini Teşrihde Devam Ediyorlar.", Babalık, 20 Teşrin-i Evvel 1927, s. 1-2.

${ }^{146}$ Balıkesir: Vilayetin Haftada Bir Defa Pazartesi Günleri Çıkar Resmi Gazetedir. 17 Teşrin-i Evvel 1927günü y1l: 13, sayı: 48-665/ 239. (Milli Kütüphane Eski Harfli Türkçe Süreli Yayınlar Toplu Kataloğunda bilgi yok.)

147 "Halk Firkası Kongresi”, Balıkesir, 17 Teşrin-i Evvel 1927, s. 1.
} 
Balıkesir gazetesi de bu kongreyi ilk büyük kongre olarak niteledi. ${ }^{148}$ Balıkesir gazetesinin 24 Ekim günkü sayısının ikinci ve üçüncü sayfasında Mustafa Kemal Paşa'nın okuduğu Nutuk'un özetlerinin verilmesine devam edildi. ${ }^{149}$

Haber gazetesinde ${ }^{150}$ daha kongre açılmadan konuyla ilgili bilgiler okuyucuyla paylaşılmıştır. "Gazi'nin Nutku" adlı haberde Mustafa Kemal Paşa'nın 15 Ekimde Ankara' da Cumhuriyet Halk Fırkası Kongresinde okuyacağı tarihi nutuklarının Türkçe yayın hakkını Türk Tayyare Cemiyeti'ne verdiği dile getirilirken, ${ }^{151}$ "Fırka Kongresi" yazısında kongreye katılmak için kimlerin Ankara'ya gideceği açıklanmıştır. ${ }^{152}$

Haber gazetesinde Büyük Nutuk'la ilgili haberler 16 Ekim tarihinden itibaren başlamıştır. Yazıda Nutuk'un kaç sayfa olduğu, yurt içi ve yurt dışından pek çok kişinin bizzat kongreye katılarak ya da gazete haberleri aracılığıyla söylenenleri takip ettiği gibi bilgiler verildikten sonra Mustafa Kemal Paşa'nın Büyük Nutuk'u milletvekili seçimlerinden önce okunacağı, ancak bazı kişiler hakkında nutukta geçen olumsuz ifadelerin -doğruluğu belgelerle kanıtlansa da- seçimlerin tarafsızlığını etkilemesini istemediği için kongreye ertelediği dile getirilmiştir. Yine Büyük Nutuk'un mazideki dokuz yılla ilgili de olsa aynı zamanda geleceğe ışık tuttuğu ifade edilmiştir. ${ }^{153}$ Haber gazetesi sonraki sayısında çerçeve içine alarak verdiği "Gazi Paşa Hazretlerinin Nutukları" adlı yazıda, locaların ilk günkü gibi doluluğu gibi fiziksel özellikleri yazdıktan sonra nutukta o gün okunanlar aktarılmıştır. ${ }^{154}$ 24 Ekim sayısında sadece fırka kongresiyle ilgili haberlere yer vermiştir. ${ }^{155}$

Kızllırmak gazetesi ${ }^{156} 13$ Ekim tarihli sayısında milletvekillerinin Cumhuriyet Halk Fırkası Umumi Kongresine katılmak için Ankara'ya

148 “Gazi Hazretlerinin İrad Buyurdukları Muazzam ve Tarihi Nutuk”, Balıkesir, 17 Teşrin-i Evvel 1927, s. 1.

149 "Reisi Cumhur Gazi Mustafa Kemal Hazretlerinin Milli Mücahedemizin İç Yüzünü Gösteren Tarihi Nutuklarının Mabad ve Hulasasıdır", Balıkesir, 23 Teşrin-i Evvel 1927, s. 23. Gazetede "devamı var" denmesine rağmen Milli Kütüphane ile Meclis kütüphanesinde sayı bulunamadi. 258.

${ }^{150}$ Haber Gazetesi, Pazartesi- Perşembe günleri neşrolunur. Afyon, sene: 5, Numara:

151 "Gazi'nin Nutku”, Haber, 12 Teşrin-i Evvel 1927, s. 1.

${ }^{152}$ Habere göre Kongreye Vilayet mutemedi Ali Necmeddin, Avukat Halil Hilmi ve Tiryakizade Hüseyin, Bolvadin belediye reisi Basri Beyler katılacaklardı. Ancak merkezin iki üye katılması kararı alması üzerine kongreye sadece Ali Necmeddin ve Halil Hilmi beyler gitmiştir. "Fırka Kongresi", Haber, 12 Teşrin-i Evvel 1927, s. 1.

153 "Büyük Nutuk", Haber, 17 Teşrin-i Evvel 1927, s. 1.

154 "Gazi Paşa Hazretlerinin Nutukları”, Haber, 19 Teşrin-i Evvel 1927, s. 1.

155 "Fırka Umumi Riyasetinin Beyannamesi", Haber, 24 Teşrin-i Evvel 1927, s. 1., "Furka Kongresi Dün Son Celsesini Akdetti”, Haber, 24 Teşrin-i Evvel 1927, s. 1.

${ }^{156}$ Kizılırmak: Cumhuriyetçi, Mefkureci, Milliyetçi Gazete. Sivas. 
gittiğini duyurduğu haberinde sadece katılımcıların isimlerini vermiş, Büyük Nutuk'la ilgili bir yorumda bulunmamıştır. ${ }^{157}$

Kızılırmak gazetesi 13 Ekim sayısından sonraki ilk baskısını 22 Ekim'de yapmıştır. Tüm sayfalarını Büyük Nutuk'la ilgili haberlere ayıran gazetede fotoğraf kullanılmamıştır. Birinci sayfada tek bir başlık vardı: "Büyük Halaskarımız Reisi Cumhur Gazi Mustafa Kemal Paşa Hazretlerinin Tarihi Nutku". ${ }^{158}$ İlk sayfada kongre açılışıyla ilgili herhangi bir yoruma gerek duymaksızın 15 Ekim tarihinden başlayarak Büyük Nutuk'un özetine devam edilmiştir. ${ }^{159}$

Mamuratül Aziz gazetesinin ${ }^{160} 26$ Teşrin-i Evvel 1927 tarihli sayısında “Gazi Paşa Hazretlerinin Nutukları” başlı̆̆ı altında Mustafa Kemal Paşa'nın okuduğu nutukla ilgili: "Reisi cumhur ve firka reisi umumisi Gazi Mustafa Kemal Paşa Hazretlerinin Cumhuriyet Halk Fırkası Kongresinde sürekli alkışlar arasında makam-ı riyaseti isggal buyurmalarını müteakip irad ettikleri küşad nutku berveche atidir." dendikten sonra diğer gazetelerde de verilen açılış nutku yer almıştır. ${ }^{161}$

Milli Gazete 162 Teşrin-i Evvel 1927 günkü sayısında haberi “Büyük Gazi Tarihi Nutuklarını İrada Başladılar” adlı yazıyla Mustafa Kemal Paşa'nın vesikalık bir fotoğrafını da ekleyerek verdi. ${ }^{163}$

Tarsus gazetesi ${ }^{164} 14$ Ekim Cuma günkü sayısında çerçeve içinde "Gazi Paşanın Nutukları" başlığıyla verdiği haberde "15 Teşrin-i Evvel cumartesi günü “Büyük halaskarımız Gazi Paşa”, hazretlerinin Büyük Nutukları Ankara telsizinden Türkiye'nin her bir yerine verilecektir" denildi. ${ }^{165} 19$ Ekim günkü sayıda ise (14 Ekimden sonraki ilk sayı) Büyük Nutuk veya kongre ile ilgili haber bulunmamaktadır.

157 "Murahhaslarımız", Kızılırmak, 13 Teşrin-i Evvel 1927, s. 1. Heykeltıraş Canonica'nın Gazi Hazretlerinin heykelini yapma amacıyla incelemelerde bulunmak için Sivas'a geleceği de bu günkü gazetede haber verildi. "Canonica Hazretleri Bu Ay Zarfında Gelecek", Kızılırmak, 13 Teşrin-i Evvel 1927, s. 1.

"Büyük Halaskarımız Reisi Cumhur Gazi Mustafa Kemal Paşa Hazretlerinin Tarihi Nutku", Kızılırmak, 22 Teşrin-i Evvel 1927, s. 1.

159 "Büyük Halaskarımız Reisi Cumhur Gazi Mustafa Kemal Paşa Hazretlerinin Tarihi Nutku", Kızılırmak, 22 Teşrin-i Evvel 1927, s. 1-4. Bir sonraki sayıya ulaşılamadı.

${ }^{160}$ Mamüratül Aziz Gazetesi, Şimdilik Carşamba Günleri Neşrolunur. Vilayet Gazetesidir, Elazı ̆̆, 26 Teşrin-i Evvel 1927 günü yıl: 44, sayı: 3078.1299 (1883) da yayınlanmaya başlamıştır.

161 “Gazi Paşa Hazretlerinin Nutukları”, Mamuratülaziz Gazetesi, 26 Teşrin-i Evvel 1927, s. 1. Nutukla ilgili başka sayı bulunamamıştır.

${ }_{162}$ Milli Gazete: Cumhuriyetçi, Halkçı, Şiyasi Türk Gazetesi. Pazartesi ve Çarşamba günleri yayınlanır. Edirne. Yıl: 1, sayı: 5 .

"Büyük Gazi Tarihi Nutuklarını İrada Başladılar", Milli Gazete, 17 Teşrin-i Evvel , s. 1 .

164 Tarsus Gazetesi, Simdilik Haftada İki Çıkar Türk Gazetesidir. Yıl: 15, sayı: 619. 1910 yılında yayınlanmaya başladı.

165 “Gazi Paşanın Nutukları”, Tarsus, 14 Teşrin-i Evvel 1927, s. 1. 
Urfa gazetesi ${ }^{166}$ ilk sayfanın yarısını "Cumhuriyet Halk Firkası'nın İlk Kongresi On Beş Teşrin-i Evvel 927 Tarihinde Saat Onda Umumi Reis Gazi Hazretleri Tarafindan Küşad Olunmuştur" başlığı altında Mustafa Kemal Paşa'nın fotoğrafıyla birlikte Büyük Nutuk'a, geriye kalan yarısını 27 Ekim tarihinde yapılacak nüfus sayımı ile ilgili haberlere ayırmıştır. ${ }^{167}$

Yozgat gazetesi ${ }^{168} 26$ Ekim tarihli sayısının ikinci sayfasında "Cumhuriyet Halk Firkası'nın Büyük Kongresi'nde Reisi Cumhur Gazi Mustafa Kemal Paşa Hazretlerinin Irad Buyurdukları Tarihi Büyük Nutuk" başlı̆̆ıyla Büyük nutkun özetlerini veren gazeteler arasında yer almıştır. ${ }^{169}$

Malatya gazetesi ${ }^{170} 13$ Teşrin-i Evvel 1927 günkü sayısında Malatya Milletvekili Nedim Bey ${ }^{171}$ ile Belediye Başkanı Hüseyin ve Cumhuriyet Halk Fırkası mutemedi Osman Hilmi Beylerin Cumhuriyet Halk Partisi Büyük Kongresine katılmak için Ankara'ya gittikleri haberini verdi. ${ }^{172} 20$ Ekim tarihli nüsha bulunmadığı için haberlere ulaşılamadı. 27 Ekim'de ise Büyük Nutuk ve kongre ile ilgili haberler verilmedi. Gazetenin beşinci seneyi devriyesi olduğu duyurulurken diğer haberler daha çok genel nüfus sayımı ile ilgiliydi. ${ }^{173}$

Büyük Nutkun okunduğu tarihlerde kütüphanede bulunan tek sayısında Nutukla ilgili haber bulunmayan diğer iki gazete de Amasya ve Yeşil Giresun'dur. ${ }^{174}$ Gazetede Büyük Nutuk'tan bahsedilmezken Mahmut Paşa'nın telgrafı ve Cumhuriyet Halk Fırkası Nizamnamesi'nin kabul edildiğine dair haber vardır. ${ }^{175}$

${ }^{166}$ Urfa gazetesi haftada bir çıkar. Vilayetin resmi gazetesidir. 24 Teşrin-i Evvel 1927 günü yıl: 3 , say1: 141 .

167 “Cumhuriyet Halk Fırkası'nın İlk Kongresi On Beş Teşrin-i Evvel 927 Tarihinde Saat Onda Umumi Reis Gazi Hazretleri Tarafından Küşad olunmuştur”, Urfa, 24 Teşrin-i Evvel 1927, s. 1.

${ }^{168}$ Yozgat çarşamba günleri neşrolunur vilayet gazetesidir. 26 Teşrin-i Evvel 1927 tarihinde yıl: 6 , say1: 308 .

169 “Cumhuriyet Halk Fırkası'nın Büyük Kongresi’nde Reisicumhur Gazi Mustafa Kemal Paşa Hazretlerinin İrad Buyurdukları Tarihi Büyük Nutuk”, Yozgat, 26 Teşrin-i Evvel 1927, s. 2-3.

${ }^{170}$ Malatya, Haftada bir neşrolunur, hükümet gazetesidir. 13 Teşrin-i Evvel 1927 günü yıl: 4, sayı: 74-208.

171 "Mebusumuz Nedim Beyefendi", Malatya, 13 Tesrin-i Evvel 1927, s. 1.

172 "Büyük Kongreye İştirak”, Malatya, 13 Teşrin-i Evvvel 1927, s. 1.

173 "Bütün Halkın Nazarı Dikkatine", Malatya, 27 Teşrin-i Evvel 1927, s. 1; "Yarınki Vazifemiz", Malatya, 27 Tesrin-i Evvel 1927, s. 1.

${ }_{174}$ Amasya: Haftalık Vilayet Gazetesi, 26 Teşrin-i Evvel 1927, Y11: 6, sayı: 281. 1338 (1922)- 1932 yılları arasında yayınlanmıştır. ; Yeșil Giresun: her hafta Perşembe gün çıkar, 20 Teşrin-i Evvel 1927, Sayı:80.

175 “Halk Fırkası Nizamnamesi Kabul Edildi”, Amasya, 26 Teşrin-i Evvel 1927, s. 1. 
Bilecik gazetesinin 11 Ekim $^{176}$ ve Çankırı gazetesinin 11 ve 25 Ekim tarihlerinde yayınlanmış sayılarında Büyük Nutuk veya Kongreyle ilgili habere rastlanmamıştır. ${ }^{177}$

Yaygın basında yazarların yorumları önemli yer tutarken, yerel basında çok az gazetede Büyük Nutuk'la ilgili makale kaleme alınmıştır. Bartın gazetesinden İbrahim Cemal "Türk Gençliği Büyük İnkılâbın Müdafiidir" başlıklı makalede: "Gazi, o selaset beyanıyla bize anlattı ki, ölüme mahkûm bir milletin kendini kurtarmasi için vatan ve istiklal aşkının kalplerde tenemmüv etmesi kâfidir. Assk bizde mevcuttu. Fakat bu imanı kuvvetlendirmek için merkezi bir dimă̆a ihtiyaç vardı ki bütün bu milli galeyanı tekşif etsin. İste yüce Gazi’nin kıymeti ve dehasının büyüklügü

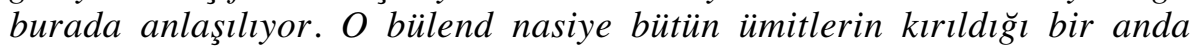
kalbindeki imanı sarsılmaksızın millete nasıl rehberlik ettiğini anlatırken Türk inkılâbının mübdiini heyecanla takdis etmemek mümkün olmuyor." sözleriyle Mustafa Kemal Paşa'nın büyüklüğü anlatıldıktan sonra gençliğin de atanın açtığı nurlu yolda hiç yılmadan ve yorulmadan yürüyeceğini ifade etmiştir. $^{178}$

Yerel basındaki makalelerden birisi de Güzel Ínebolu gazetesinde ${ }^{179}$ Musa Kazım ${ }^{180}$ tarafından kaleme alınmıştır. "Gazinin Nutukları" adlı yazıda yazar: "Türkün fevkelbeşeri yüce Gazi, bütün dünyanın alaka ve heyecanla beklediği tarihi nutkunu irad buyurdular. Gazi hazretlerinin baştan başa bir şaheser olan büyük ve uzun nutku Ankara'da görülmedik bir galebenin huzurunda dinlendi.... Onu dinleyenler ne kadar iftihar etseler yine azdir. Türk Cumhuriyetinin banisi Gazi hazretleri irad buyurduklarl nutkuyla yeni Türkiye'ye, Cumhuriyet nesline klymetdar bir tarih, hem öyle bir tarih ki, asırlar geçse, nesiller de ğisse, bu kadar derin bir tedkik vukuf ile meydana getirilmesi kabil olmayan bir eser. Kendi yarattı ğını kendi istikamet verdiğ $i$ tarihi, hakikatleri bizzat kendinden dinlemek ve öyle bir esere malik olmak bahtiyarlık değil midir? Gazinin dinlemek ve okumaya doyulmayan ve bütün dünya lisanlarına tercüme edilen nutku ...Türkün yeni dünyadaki tarihinin müstesna bir başlangıcı kalacaktır."181 sözleriyle duygularını dile getirmiştir. say1: 137.

${ }^{176}$ Bilecik Gazetesi, Vilayetin Resmi Gazetesidir,11 Teşrin-i Evvel 1927 günü yıl: 3,

${ }^{77}$ Çankırı Gazetesi, Salı Günü Neşrolunur Vilayet Resmi gazetesidir, 11 ve 25 Teşrin-i Evvel 1927. Y1l: 6, sayı: 263-265. (Milli Kütüphane Eski Harfli Türkçe Süreli Yayınlar Toplu Kataloğunda bilgi yok.)

178 İbrahim Cemal, “Türk Gençliği Büyük İnkılabın Müdafiidir”, Bartın Gazetesi, 24 Teşrin-i Evvel 1927, s. 1.

179 Güzel İnebolu: İktisadi, İçtimai, Edebi ve Cumhuriyetperver Haftalık Türk Gazetesidir. 27 Teşrin-i Evvel 1927 günü yıl: 4, sayı: 125. 1921 yılında yayınlanmaya başladı.

${ }_{180}$ Güzel İnebolu gazetesi diğer gazetelerden farklı olarak Büyük Nutuk'la ilgili haberleri Anadolu Ajansı'ndan değil, muhabiri Musa Kazım Bey'in yorumlarıyla vermiştir.

${ }^{181}$ Musa Kazım, "Gazinin Nutukları", Güzel İnebolu, 27 Teşrin-i Evvel 1927, s. 1. 
Hür Fikir gazetesinin ${ }^{182} 18$ Ekim 1927 tarihli sayısında Kumandanoğlu imzasıyla yazılan bir makale de "Büyük Kongre, Büyük Gazi" adını taşımaktadır."183 31 Teşrin-i Evvel 1927 günkü Hür Fikir gazetesinde de Büyük Nutuk'la ilgili olarak Yakup Kadri’nin Hâkimiyet-i Milliye gazetesinde çıkan "Büyük Nutkun Faideleri" adlı yazı dizisi yayınlanmıştır. ${ }^{184}$ Hür Fikir gazetesinin 31 Ekim tarihinde Büyük Nutuk'la ilgili diğer yazısı "Gazi ve Times Gazetesi" adlı yazı da Hâkimiyet-i Milliye gazetesinden aktarılmıştır. ${ }^{185}$

Milli Gazete başyazarı Haşim Cevdet "Gazi ve Ankara" adlı yazısında şehirlerin kimisinin doğal güzellikleri veya başka özellikleriyle kendini unutulmaz kıldığından bahisle Ankara'nın önemini belirttiği makalesinde: “...milyonlarca kalp yolunun nihayet bulduğu Çankaya'sı, Türkün milli emelinin Kabe'si oradır" diye yazmıştır. ${ }^{186}$ Haşim Cevdet Bey 20 Ekim 1927 tarihinde de "Gazinin Eseri" adlı makalesinde Nutuk'un günlerden beri merakla beklenildiğini, en büyük mucizenin yaratıldığı anın geldiğini, bu mucizeyi yaratan kişinin (bu yeni ve muazzam binanın banisi odur sözleriyle) Mustafa Kemal olduğunu, onun düşünüp onun yaptığını dile getirmiştir. ${ }^{187}$ Büyük Nutuk okunmasının hemen ardından yazılan

${ }^{182}$ Hür Fikir: Cumhuriyette Hakim Kanundur, Halaskar Ulu Rehberimizin İzinde Yürüyen: Dini, İçtimai, Siyasi, Edebi, İnkılapçı Cumhuriyet Gazetesidir. Yı1: 4, sayı: 189. Haftalık, İzmit.

${ }_{183}$ Makalede: "Kendisine has olan bir azim ve irade tarihi cihanda hiç tesadüf edilemeyen bir metanet ve besalet fevkalade ile yine cihanin bütün vesaiti harbiyesini istihkar ederek yorgun ve hatta solgun görünen milletin başına geçen büyük Gazi, her müşkülata ve sonsuz tehdidata rağmen Sivas'ta yeni bir devlet doğuran cok büyük bir kongre akd ve onu müteakip emsalsiz bir mücadeleye atılmıștı. Sekiz sene devam eden bu mücadelenin her safhasinda Gaziyi bir elinde yalın kllıç, diğerinde meşale-i irfan ve kemalet olduğu halde görürüz. Esaret ve zulmü kendisine layı görmeyen her insan yeni ve hak peygamberin izini takip etmeye basslamıştl. Onun izi üzerinden yürüyenler, hürriyet ve insaniyetin ulviyetini çok yakından gördüler. Gazi diyordu bize istiklal veyahud ölüm! Sivas kongresinin bu güne kadar geçen müddet zarfinda Büyük Gazi Türkün hatta insaniyetin vakur alnını güneșlerin bile erişemediği yükseklere isal etmistir...927 Ankara Kongresinin en hararetli anlarındayız. Büyük Gazi bu kısa zamanın tarihine sığamayacak kadar büyük olan vekaın yarattığ gibi izah ediyor. Gazinin yirminci asra laysk ve Türk milletini en fiyaz bir saadete eristiren uluazam bir hak peygamberi bulunduğu cihanın bir vecdi hürmetkeranesiyle tasdik ve tesellüm eyledikleri hevarık adidesiyle teyid oldu...Gazi Mustafa Kemal, Türklü̈̆üun kalbinde yaşayan çok ulu bir çınardır." denmekteydi. Kumandan Oğlu, "Büyük Kongre, Büyük Gazi”, Hür Fikir Gazetesi, 18 Teşrin-i Evvel 1927, s. 1.

${ }_{184}$ Gazete haberi okuyucularına su sözlerle duyurdu: "Klymetli maarif ediplerimizden, muhterem mebuslarımızdan Yakup Kadri Bey bu serlevha altında bir mülakat silsilesi neşredecektir. Bunları aynen iktibas ederek Hür Fikir karilerine takdim edeceğiz. Çünkü bu yazılar aynı zamanda Hür Fikir'in kanaatlerini tayin ve tevsik etmektedir. Kailerimiz ehemmiyet ve dikkatle okusunlar." Yakup Kadri, "Büyük Nutkun Faideleri”, Hür Fikir Gazetesi, 31 Teşrin-i Evvel 1927, s. 1.

185 "Gazi ve Times Gazetesi”, Hür Fikir Gazetesi, 31 Teşrin-i Evvel 1927, s. 1, 4.

${ }^{186}$ Haşim Cevdet, "Gazi ve Ankara", Milli Gazete, 17 Teşrin-i Evvel 1927, s. 1. Haşim Cevdet'in bu yazısı yerel basında Büyük Nutuk'un başkent Ankara ile birlikte işlendiği tek makaledir.

${ }^{187}$ Haşim Cevdet, “Gazinin Eseri”, Milli Gazete, 20 Teşrin-i Evvel 1927, s. 1. 
makalelerde onun geçmişi anlamak için tarihi bir kaynak olduğuna vurgu yapılmış, önerilen tarihi bir kaynak şeklinde de gösterilmiştir. ${ }^{188}$

Büyük Nutuk okunduktan sonra Çürüksulu Mahmut Paşa'nın yolladığı telgraf yaygın basında olduğu gibi yerel basında da büyük ilgiyle karşılanmıştır. Açıksöz gazetesinin 23 Ekim günkü sayısının birinci sayfasında Çürüksulu Mahmut Paşa'nın telgrafi ${ }^{189}$ ile Cumhuriyet Halk Fırkası Genel Sekreteri (Reşit) Saffet Beyin nutkun eklerini oluşturan belgeler yayınlandı̆̆ında, gerçeklerin herkes tarafından daha iyi anlaşılacağını dile getiren bir telgrafı da aynı gazetede yayınlanmıştır. ${ }^{190}$ Açıksöz gazetesi 24 Ekim günü ilk sayfasını Cumhuriyet Halk Fırkası

${ }^{188}$ Hüseyin Hilmi makalesinde:“O günün ulviyet ve kutsiyetini, o günün ne kadar çetin mücadelelerle elde edildiğini anlamak için büyük mürşit ve halaskarımızın son defa Cumhuriyet Halk Fırkası Kongresi'nde irad buyurdukları tarihi hitabelerini okumak kâfidir." demektedir. Hüseyin Hilmi, "Milli ve Hakiki Bayram", Sinop Gazetesi, 27 Teşrin-i Evvel 1927, s. 1 .

189 “Çürüksulu Mahmut Paşa'nın Telgrafı”, Açıksöz, 23 Teşrin-i Evvel 1927, s. 1.

190 “Çürükssulu Mahmut Paşa'nın Telgrafı”, Açıssöz, 23 Teşrin-i Evvel 1927, s. 1. Haberde "Bu telgrafa Cumhuriyet Halk Fırkası Katib-i umumiliği tarafindan atideki cevab verilmiștir: "Fırkamızın büyük kongresinde umumi reisimiz Gazi Hazretlerin beyanatları üzerine çektiğiniz telgraf alındı. Vesaik kariben neşrolunduğu zaman Gazi hazretlerinin beyanatlarının gayrı kabil-i tereddüd esasata müstenid olduğu ve hatta daha ağır mevzular üzerinde ne kadar müsamahakar bulundukları görülecektir efendim. Cumhuriyet Halk Firkası Katib-i Umumisi Saffet. (bu yazı da vakit ve Cumhuriyet gazetelerinde 23 Ekimde yayınland..)"Neşrettiğimiz vesaik büyük reisimizin bahiste temas ettikleri bütün vekaiyede en küçük teferruatı bile ihmal buyurmadıklarına ve gayrı kabil-i tekzip vesikalara isnaden irad (mekal) eylediklerini göstermektedir. Mahmut Paşanın 31 Teşrin-i Evvel 335 tarih ve 2887 numrulu tasvir-i Efkar gazetesinde çıan beyanatı aynen şu sözler mevcuddur: "Ermenilerin fazla (muttalibatına) hak vermeksizin hudutlarda bazı tashihatın icrasina razı oluruz. Bize göre Amerika mandası tayin edilecek bazı şerait dahilinde kabil-i kabuldür. Bu beyanat üzerine Gazi hazretlerinin Anadolu ve Rumeli Müdafaa-i Hukuk Cemiyeti heyet-i temsiliyesi namina Mustafa Kemal imzasıyla ve 17.11. 35 tarihiyle Sivas'tan çektikleri telgrafname aynen şudur: Çürüksulu Mahmut Paşa hazretlerine, 31 Teşrin-i Evvel 335 tarihli Tasvir-i Efkar gazetesinde Bosfor gazetesi muharrirlerinden birine vaki beyanat devletlerinde Ermenilerin fazla mutalebatına hak vermeksizin hudutlarda bazı tashihatın icrasına razı oluruz denildiğini okuduk. Şarki Anadolu'da Ermenistan lehine tavizat-l arızıyede bulunulduğu ve adını muttezımen olan bu cümlenin sulh komisyonu azasından bir rical-i devlet tarafindan sarf edilmiş bulunmasının Şarki Anadolu ahalisinin pek muhakkak olarak son derece mucib-i (infaal) ve temini olduğunu beyan eyleriz. Miletin Erzurum ve Sivas Kongreleri mukarreratı ile Ermenistan'a bir karış toprak terk etmeyeceği ve hatta hükümet bu kabil bir mecburiyet alimiye ser furu eylemek iztırarında kalsa bile kendi hukuk -u mesruiyesini bizzat müdafaya azim eylemis bulunduğu cihana ilan edilmis olduğundan bu azim ve karar-l milliden herkesten evvel istihzarat-l sulhiye komisyonu azayl kiraminca malum ve muttali bulunması lüzumunu arz ederiz. Bu müsvedde o zaman Gazi Hazretlerinin yanında bulunan elyevm Sofya sefiri Hüsrev Beyin parasıyla tesvid olunmuștur. Altında kapızından evvel taraf devletlerinden görüldü̈g̈̈nü gösteren m.k. işareti vardır. Yazıldı ğına dair Hayati Bey merhumun imzasını havi yazıldı 18 h. kaydı ve kağıdın săg alt kösesinde bir sureti Şarki Anadolu Heyet-i merkeziyesine ve gazeteye ibaresi bulunur. O zamanda katip bulunan Memduh Beyin imzası üzerinde İrade-i Milliye'ye gönderildi. 22 Teşrin-i Sani 335 kaydının mevcud olması bu telgraf suretinin o vakit Sivas'ta çıan Irade-i Milliye gazetesiyle neşredilmiş olduğunu göstermektedir. Bu vaziyet karşısında Çürüksulu Mahmut Paşa'nın izamına mahal olup olmadığının takdiri fi karilere bırakıyoruz”. denmekteydi. 
Kongresince kabul edilen beyanname metnine ayırmıştır. ${ }^{191}$ Babalık gazetesi de Çürüksulu Mahmut Paşa'nın telgrafı ve Cumhuriyet Halk Fırkası Genel Sekreteri Saffet Bey'in yanıtını Açıksöz gazetesindeki hemen hemen aynı satırlarla vermiştir. ${ }^{192}$ Amasya gazetesi sayfalarında Büyük Nutuk ile ilgili haberlere yer vermezken bu konuyu "Mahmut Paşa'nın Telgrafı" adlı yazıda işlemiştir. ${ }^{193}$

Hizmet gazetesi Çürüksulu Mahmut Paşa olayını manșete taşımıs ve Mahmut Paşa'ya: "Hiç olmazsa anlamalıdır ki Gazi şimdiye kadar olmayan şeyi söylememiş, söylediklerini de mutlaka tahkik ettirmiştir. İşte bu vesika ki Çürüksulu Mahmut Paşa'nın çürümeden bir noktasını dahi bırakmıyor" sözleriyle seslenmiştir. ${ }^{194}$

Gençliğe Hitabe okunduktan sonra yerel basına bakıldığında, yaygın basındaki kadar olmasa da hemen hemen incelenen tüm gazetelerde bu habere yer verildiği dikkati çekmektedir. Babalık gazetesi, 25 Ekim günkü ilk sayfasını konuyla ilgili haberlere ayırmıştır. "Gençliğin Ahdi ve Şükranı" başlıklı yazıda "Darülfünun talebesi içtima ederek Cumhuriyetin muhafazası uğrunda hiçbir fedakârlıktan çekinmeyeceklerini ahd ettiler." dedikten sonra gençliğe hitabın ardından üniversiteli gençlerin toplanarak Mustafa Kemal Paşa'ya telgraf çektikleri haberini vermiştir. ${ }^{195}$ Gençliğe hitabe haberi Açıkgöz gazetesinin 22 Ekim günkü ikinci sayfasında yer bulmuştur. ${ }^{196}$

Mustafa Kemal Paşa'nın Büyük Nutuk'u Gençliğe Hitabe ile bitirmesi üzerine Ankara ve İstanbul Üniversiteleri'ndeki gençlerin yaptığ Ahenk gazetesinde okuyucularla paylaşılan haberler arasında yer almıştır. ${ }^{197}$

Gazi Mustafa Kemal Paşa'nın, Büyük Nutuk'u Gençliğe hitabe ile bitirirken döktüğü gözyaşlarını Hizmet gazetesi çerçeve içinde ve "Büyük

191 "Kongre Umumi Riyasetinin Beyannamesi”, Açıksöz, 24 Teşrin-i Evvel 1927, s. 1.

192 "Tarihi Bir Hakikatin İspatı", Babalık, 24 Teşrin-i Evvel 1927, s. 1-2.

${ }^{193}$ Çürüksulu Mahmut Paşa olayı gazetede: "Sabık ayandan Çürü̈ksulu Mahmut Paşa Reisi Cumhur hazretlerine bir telgraf göndererek Büyük Nutuk'un kendisinden bahis kısmında bir yanlışlık olduğunu, kendisinin Şark hudutlarımızda Ermenistan lehine tashihe razı olacağ tarzında gazetelere beyanatta bulunmadı ̆̆ını ve Gazi Paşa hazretlerinden ikaz ve tashihi bir telgraf aldı ğını tahattür edemediğini bildirmistir." ş̧ şlinde yorumlanarak verilmiştir. "Mahmut Paşa'nın Telgrafı", Amasya, 26 Teşrin-i Evvel 1927, s. 1.

194 "Büyüklüğün Vasf,”, Hizmet, 24 Teşrin-i Evvel 1927, s. 1-2.

195 "Gençliğin Ahdi ve Şükranı", Babalık, 25 Teşrin-i Evvel 1927, s. 1.

196 "Reisi Cumhur Hazretlerinin Türk Gençliğine Hitabeleri", Açıksöz, 22 Teşrin-i Evvel 1927 , s. 2. Haberde Mustafa Kemal Paşa'nın nutku okumayı bitirdikten sonra yaşananlar da ayrıntısıyla ifade edildi. Buna göre katılımcılar heyecanlanarak uzun süre alkışladılar. Kongre Mustafa Kemal Paşa'nın nutkunun kongre tarafından teşekkür ve minnetle tasvip edilmesini ve fırka defterine geçilecek işbu tasvip kararının kongreye iştirak eden bilumum murahhaslar tarafından imzalanmasını teklif eden Erzurum milletvekili Necip Asım Bey'in takririni oybirliğiyle kabul etmiştir. Gazi cumartesi öğleden sonra içtima edilmek üzere celseyi terk ederken salon devamlı alkışlarla çınlıyordu. Gazi hazretlerinin nutukları 36 saat 33 dakika sürmüstür.

197 “Büyük Gazinin Hitabesi ve Gençlik”, Ahenk, 23 Teşrin-i Evvel 1927, s. 1. 


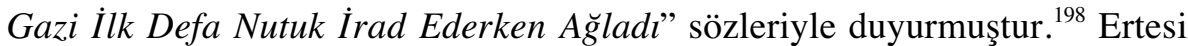
günkü sayıda gençliğin Gazi’ye cevabının bulunacağı duyurulmuş ve 24 Ekim günkü gazetede bu cevap yayınlanmıştır. ${ }^{199}$ Darülfünun gençlerinin toplanması da ayrıntılı bir şekilde okuyuculara aktarılmıştır. ${ }^{200}$

Balıkesir gazetesinin 24 Ekim günkü sayısı Mustafa Kemal Paşa'nın fotoğrafıyla birlikte Gençliğe Hitabe'ye ayrılırken ${ }^{201}$, sayfanın diğer yarısında "İki Mesud Bayram" başlığıyla Cumhuriyet Bayramı ve Büyük Nutuk ele alınmıştır. Yerel basında ilk defa Ballkesir gazetesi Cumhuriyet Halk Fırkası Kongresi ve Büyük Nutuk'la Cumhuriyet bayramını birlikte değerlendirmiştir. ${ }^{202}$

Milli gazete, 24 Ekim günkü sayısında Mustafa Kemal Paşa'nın okuduğu Gençliğe Hitabeye geniş yer ayırmıştır. Konuyla ilgili yazılardan biri ilki "Gazi'nin Hitabesi" diğeri "Gazi Hazretlerinde Gençlik" idi. ${ }^{203}$

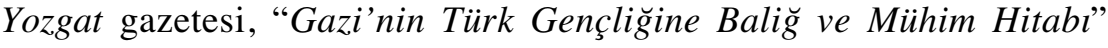
adıyla verdiği haberde Mustafa Kemal Paşa'nın Cumhuriyet Halk Fırkası Kongresi'nde altı günden beri devam eden tarihi nutuklarının saat 21 'de son bulduğunu belirtmiştir. ${ }^{204}$

Büyük Nutuk'un okunmasının ardından yerel basında çıkan haberlerden birisi de, Mustafa Kemal Paşa'nın mal varlığının büyük bir kısmını partiye bağışlamasıyla ilgilidir. Bu haber Açıksöz gazetesinde 20 Ekim günkü birinci sayfanın sol üst köşesinde Mustafa Kemal Paşa'nın tüm mal varlığını fırkaya bağışladığı sözleriyle çerçeve içinde özel haber olarak verilmiştir. ${ }^{205}$ Urfa gazetesinin 24 Ekim günkü ikinci sayfasında: "Büyük Gazi Cumhuriyet Halk Fırkasının Vatanı Mesaiyesine Olan İtimadlarını Yeniden Teyid Buyurdular"

198 “Büyük Gazi’nin muazzam tarihi nutuklarının husule getirdiği heyecan devam etmektedir. Gazinin senelerden beri yanında bulunmus olanlar büyük Türkün, hayatında ilk defa olarak nutuklarını irad ederken ağladığını görmüşlerdir.", "Büyük Gazi İlk Defa Nutuk İrad Ederken Ağladı", Hizmet, 23 Teşrin-i Evvel 1927, s. 1.

199 "Yarın: Gençliğin Gazi’ye Cevabı, muharriri: Zeynel Besim”, Hizmet, 23 Teşrin-i Evvel 1927, s. 1.; "Gençliğin Gaziye Cevabı", Hizmet, 24 Teşrin-i Evvel 1927, s. 1. Gençliğin Ataya cevabı yaygın basındaki aynı metindir. 3.

200 “Darülfünun Gençleri Darülfünun'da Toplandı”, Hizmet, 24 Teşrin-i Evvel 1927, s.

201 "Reisi Cumhur Hazretleri Gençliğe Hitap Buyuruyorlar", Balıkesir, 24 Teşrin-i Evvel 1927, s. 1.

202 “İki Mesud Bayram”, Balıkesir, 24 Teşrin-i Evvel 1927, s. 1.

203 "Gazi Hazretlerinde Gençlik”, Milli Gazete, 24 Teşrin-i Evvel 1927, s. 1.

204 “Gazi'nin Türk Gençliğgine Baliğ ve Mühim Hitabı”, Yozgat, 26 Teşrin-i Evvel 1927, s. 1. "Reisicumhur hazretleri tarihi nutuklarının izahını müteakib, Türk gençliğine hitaben şiddetli ve sürekli alkışlar (yaşa var ol) sesleriyle mütemadiyen inkıtaa uğratılan atideki hitabeyi irad buyurmuşlardır. Muhterem efendiler...”...diye başlayan gençliğe hitab kısmı burada da tekrar ediliyor.

205 "Büyük ve Mübeccel Dahimiz Bilumum Emval ve Emlaklarını Fırkaya Tebeddü Buyurdular", Açıksöz, 20 Teşrin-i Evvel 1927, s. 1. 
başlı̆̆ıyla yaygın basındaki konuyla ilgili haberler tekrar edilmiştir. ${ }^{206}$ Urfa gazetesinin 31 Ekim tarihli sayısının ilk sayfası Cumhuriyet bayramı ile ilgili haberlere, ikinci sayfanın tamamı İsmet Paşa'nın Büyük kongredeki kapanış konuşmasına ayrılmıştır. Sayfanın tam ortasında da İsmet Paşa'nın fotoğrafı verilmiştir. ${ }^{207}$ Urfa gazetesi haberlerinde diğer yerel gazetelerden farklı olarak İsmet Paşa'ya Mustafa Kemal Paşa kadar eşit yer vermiştir.

Yaygın ve yerel basın arasındaki farklardan biri de Nutuk'ta Mustafa Kemal Paşa tarafından eleştirilen kişilere gazetelerde yer verilmesi/verilmemesidir. Yaygın basında, bu kişilere nutukta geçen ifadelerden daha ağır ithamlarda bulunulurken, yerel basında konuya hiçbir gazete değinmemiştir.

Büyük Nutuk okunduktan sonra ülkenin değişik yerlerinden ve sivil toplum örgütü ve kişilerden Mustafa Kemal Paşa'ya bağlılıklarını dile getiren telgraf ve mektuplar yollanmıştır. Hâkimiyet-i Milliye gazetesi bu haberleri sayfasında ayrıntılı bir şekilde ve çerçeve içinde yer verirken, ${ }^{208}$ yerel basında Mustafa Kemal Paşa'ya telgraf çekildiğine dair haberlere ${ }^{209}$ Ahenk, Haber ve Hizmet gazeteleri yer vermiştir.

Ahenk gazetesi İzmir Tayyare Cemiyeti ve Bornova Türk Ocağı'nın Mustafa Kemal Paşa'ya yolladığı telgrafları ${ }^{210}$ ve Mustafa Kemal Paşa'nın Tayyare Cemiyeti'ne gönderdiği teşekkür telgrafını okuyucularıyla paylaşırken ${ }^{211}$ İzmir Türk Ocağ $1^{212}$ ve İzmir Tayyare Cemiyeti'nin ${ }^{213}$ Gazi'ye çektiği teşekkür telgrafı Hizmet gazetesinde de yayınlanmıştır.

206، Büyük Gazi Cumhuriyet Halk Fırkası'nın Vatanı Mesaiyesine Olan İtimadlarını Yeniden Teyid Buyurdular", Urfa, 24 Teşrin-i Evvel 1927, s. 2.

207 "İsmet Paşa Hazretleri Büyük Kongrede Fırkanın Programını, Dahili ve Harici Siyaset Mesnetlerini Bütün Vuzuhuyla İfade Buyurdular”, Urfa, 31 Teşrin-i Evvel 1927, s. 23 .

${ }^{208}$ Hâkimiyet-i Milliye gazetesindeki haberler için Bkz. 116. dipnot.

${ }^{209}$ Yerel basında özel günlerde Mustafa Kemal Paşa'ya (ve diğer yöneticilere) çekilen telgraflar ve Anadolu Ajansı aracılı̆̆ıyla gelen yanıt genelde gazetenin birinci sayfasında verilmektedir.

210 "Büyük Gazimizin muazzam hitabeleri münasebetiyle işaret buyurdukları hakikatlerden doğan heyecan her tarafta devam etmekte, gençlik ve muhtelif teşkilat ulu Gazimize hissiyat ve sükranlarını ve tazimatlarını arz eylemektedirler. Sehrimiz Tayyare Cemiyeti ve Bornova Türk Ocă̆g Gazi Hazretlerine atideki telgraflarl keşide etmişlerdir...", "Büyük Gaziye Tayyare Cemiyeti'nin Tazimatı", Ahenk, 26 Teşrin-i Evvel 1927, s. 2.

211 "Büyük Gazinin İltifatı, Muazzam hitabeleri münasebetiyle İzmir Tayyare Cemiyeti'nin arz edilen heyecan ve hissiyat ve tazimatına büyük reisi cumhurumuz yüce Gazi hazretleri atideki telgrafla mukabele ve iltifat buyurmuşlardır: İzmir Tayyare Cemiyeti reisi Mehmet Şevki Beye: Telgrafnamenizi aldım. Hitabemin, gençliğimizin ve büyük milletimizin ruhunda uyandırdığ 1 necip akisleri dinlemekten pek müftehir ve mesudum. Milli azim ve şuurun zade-i feymetdarı, aziz cumhuriyetin nesli hazır ve müstakbelin demir ellerinde her an müteali ve payidar olacağına itimadım bir kemaldir. Şahsıma karşı izhar buyurulan asar-1 teveccühe teşekkürler ederim. Reisi Cumhur Gazi Mustafa Kemal”, "Büyük Gazi’nin İltifatı", Ahenk, 29 Teşrin-i Evvel 1927, s. 1.

212 “Ankara'da Ulu Gazi'ye”, Hizmet, 24 Teşrin-i Evvel 1927, s. 1.

213 "Ulu Gazi'ye", Hizmet, 26 Teşrin-i Evvel 1927, s. 1. 
Haber gazetesi sadece Afyon Karahisar Türk Ocağı'nın Mustafa Kemal Paşa'ya çektiği telgrafı gazetede yayınlamakla yetinmiş, gelen yanıt paylaşılmamıştır. $^{214}$

Büyük Nutuk sonrasında yurt dışındaki yansımaları yaygın basının tamamına yakınında işlenirken, ${ }^{215}$ yerel basında bu olaya Hür Fikir ve Ahenk gazeteleri değinmiştir. Ahenk gazetesi, ${ }^{216} 26$ Ekim'de yayınlanan "Gazinin Rekoru: Taymsın Baş Makalesi" adlı haberde: "Tayms gazetesi Gazi hazretlerinin muazzam nutuklarl münasebetiyle "Gazi'nin Rekoru" serlevhası altında mühim bir baş makale neşretmiştir. Times bu baş makalesinde Gazi Hazretlerinin nutuklarından takdirkarane bahsederek

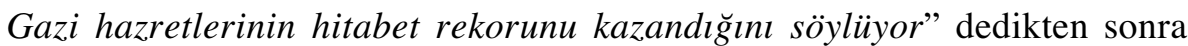
makaleyi özetleyerek vermiştir. 29 Ekim tarihli Ahenk'de ise Tayms gazetesinin bir sonraki sayısında devam eden yazı dizisi hakkında bilgiler verilmiştir. $^{217}$ Gazetede Büyük Nutuk ile ilgili haberler yanında kongre hakkında da haberler devam etmiştir. ${ }^{218}$ Büyük Nutuk ile ilgili haberlerin

214 “Gazi Paşa Hazretlerinin Cumhuriyet Halk Fırkası'nda irad buyurdukları nutuk üzerine Afyon Karahisar Türk Ocağ Gazi Mustafa Kemal Pasa hazretlerine, Ulvi hitabeniz hepimizin ruhunda derin akisler ve vatanpervarane tahsisler uyandırdı. Bu münasebetle karahisar gençliğinin istiklal ve cumhuriyet mefhumlarına ebedi ve kırllmaz bir kalb rabıtast ile merbut ve içinde her türlü fedakarlığı ifaya azim bulunduğınu tekrar eyler, ocă̆ımızın tazimatını arz eyleriz efendim.", Haber, 26 Teşrin-i Evvel 1927, s. 1.

215 "Tayms Gazetesi De Gazimizin Dehasına Ve Kudreti Beyanına Hayran!", Cumhuriyet, 26 Teşrin-i Evvel 1927, s. 1; "Gazinin Nutku”, Milliyet, 26 Teşrin-i Evvel 1927, s. 1-2; "Tarihi Nutuk Avrupa Matbuatı Tarafından Pek Büyük Bir Ehemmiyetle Karşılandı", Milliyet, 27 Teşrin-i Evvel 1927, s. 3.; "Reisicumhur Hazretlerinin Nutukları Hakkında İngiliz gazeteleri Neler Söylediler”, Vakit, 26 Teşrin-i Evvel 1927, s. 1.

216 "Gazi'nin Rekoru", Ahenk, 26 Teşrin-i Evvel 1927, s. 1.

${ }^{217}$ Haberde: "Tayms gazetesinin tarihi nutku için bir bas makale tahsis etmis, İstanbul işgalinden yalnız Ingiltere’nin mesul olmadığını göstermek istemistir. Tayms gazetesinin dün gelen nüshası Gazi Hazretlerinin Halk Fırkası kongresinde irad buyurdukları altı gün devam eden büyük ve tarihi nutkuna bir makale tahsis etmistir. Bu günkü Tayms ise nutkun hitamindan sonra hasıl olan umumi tesiri hasıl etmektedir. Ístanbul'daki muhabiri tarafindan bir telgraf seklinde gönderilerek intisar eden bu umumi tahlilde ez cümle deniliyor ki: "gazi Pasa'nın muazzam nutuklar hitam bulmus ve suretle bir devlet reisinin milletine verdiği en muhteşem tarihi ders nihayete ermistir. Muhabir bundan sonra nutkun bazı münakaşalar tevlid edece ğini, fakat her halde Gazi'nin tac-l muzafferiyete yeni bir celik ilave ettiğini söylemektedir. Tayms muhabiri diyor ki: "Nutuk bir akid ile ihzar olmuş, mükemmel bir sekilde irad edilmis Türk efkar-ı umumiyesi üzerinde kuvvetli bir tesir icra edeceğ zamanda irad olunmustur."Tayms muhabiri nutuk hakkında bilhassa diyor ki: Harici bir nokta-i nazardan tedkik olunduğu takdirde Gazinin nutku hakkında başlıca söylenilecek söz, onun İstanbul'u işgal hususunda umumiyetle müttefikleri değil, yalnız Ingiltere'yi mesul göstermesidir. Nutukta "Ingiltere" kelimesi madud defalar tekrar etmistir. Asri Türkiye'nin Ingiltere hakkında zerre kadar aleyhderane düşünmesi şayanı telhifdir. Bilhassa Reisi cumhur ile baslıca arkadaslart efkarı umumiyeyi Ingiltere aleyhinde tahrik etmek istemediklerini bildiğim için bu nokta daha şayanı tesir olmaktadır. Taym muhabiri bunu müteakip Gazi Paşanın nutkunun son aksamindan bahsetmektedir.”denilmektedir. "Gazi'nin Nutku", Ahenk, 29 Tessin-i Evvel 1927, s. 2.

218 "Kongre Fırkanın Nizamnamesini Kabul Etti”, Ahenk, 23 Teşrin-i Evvel 1927, s. 1.; "Fırkamızın Yeni Nizamnamesinin Umumi Esasları", Ahenk, 23 Teşrin-i Evvel 1927, s. 2. 
verilmesinde yaşanan sorundan dolayı Ahenk gazetesi Anadolu Ajansını sayfalarından okuyucularına şikayet etmiştir. ${ }^{219}$

Hür Fikir gazetesinde hangi kaynaktan alındığı belirtilmeyen yazıda yaygın basındaki bilgiler yanında farklı notlara da yer verilmiştir. ${ }^{220}$

Hizmet gazetesi diğer yerel gazetelerden faklı olarak iki uygulamaya imza atmıştır. Ankara'da kongreye katılan milletvekili Onur Bey'le röportaj yapmış, sadece Onur Bey'in değil, Mecliste Büyük Nutuk'u dinleyen diğer katılımcıların hislerini de okuyucularına şikayet etmiştir. ${ }^{221}$ Ayrıca yaygın basında sadece Hakimiyet-i Milliye gazetesinde yayınlanan Mustafa Kemal Paşa'nın kendisine gönderilen telgraflara verdiği yanıtlar yerel basında Hizmet gazetesinde yayınlanmıştır. ${ }^{222}$

Yaygın basında Büyük Nutuk ile ilgili bilgiler verilirken haberler fotoğrafla desteklenmiştir. Bu fotoğraflarda Mustafa Kemal Paşa'nın Meclise gelişi, Mecliste nutku okuduğu sıradaki hali veya nutukta adı geçen kişilerin daha küçük boydaki resim veya fotoğrafları ile Meclis binası ile Sivas'taki Kongrenin yapıldığ yazılarında genelde kişilerin kim oldukları yazarken bazılarında yorumlar da yapılmıştır. ${ }^{223}$ Yerel basındaki gazetelere bakıldığında ise, bu dönem fotoğrafa yer verilmediği görülür. Haberlerine fotoğraf ekleyen gazetelerse çoğunlukla Mustafa Kemal Paşa'nın portrelerini kullanmışlardır. Yerel basındaki haberlerde fotoğraf kullanılmamasının nedenlerinden biri de bu yıllarda Anadolu'da gazete basılan matbaaların dizgilerinin ilkel, baskı makinelerinin güçleri ve hızlarının sınırlı olmasıdır.

\section{SONUÇ}

Mustafa Kemal Paşa, Büyük Nutuk’u Üçüncü Büyük Millet Meclisi'ne tek parti olarak gelen Cumhuriyet Halk Fırkası'nın düzenlediği kongrede 1520 Ekim tarihleri arasında okumuştur. Aç1lış konuşmasında "İstikbale ait tedabire müteallik medarın efkârda bulunmadan evvel maziye ait vekayi ve hadisat hakkında maruzatta bulunmak senelerden beri devam eden efal ve icraatımızın milletimize hesabını vermek vazifem olduğu kanaatindeyim. Dokuz senelik bir devrenin tarihine temas edecek maruzat ve beyanatım

${ }^{219}$ Anadolu Ajansı haberleri öğleden sonra geçince akşam gazetesi olan Ahenk bu durumdan olumsuz etkilenmiştir. Sabahçı gazete Hizmet ise bu olumsuzluktan etkilenmemiştir. "Anadolu Ajansı’na Meram Anlatamadık”, Ahenk, 29 Teşrin-i Evvel 1927, s. 2 .

220 “Gazi ve Times Gazetesi”, Hür Fikir Gazetesi, 31 Teşrin-i Evvel 1927, s. 1, 4.

221 "Gazi Muhakkak ki Fevkelbeşerdir", Hizmet, 27 Teşrin-i Evvel 1927, s. 1.

222 "Büyük Gazi”, Hizmet, 31 Teşrin-i Evvel 1927, s. 1.

${ }^{223}$ Milliyet gazetesi 16 Ekim tarihi Sivas Kongresi sonrasında çekilen fotoğrafın altındaki açıklama yazısında: "Yeni Türk Devleti'nin banisi Gazi Mustafa Kemal Hazretleri mücahede ve mücadelede kendisine ve inkllaba sadık kalan veya muharı ve muhalif kesilen zevat ile beraber Sivas Kongresinde” yorumu yapılmıştır. Milliyet, 16 Teşrin-i Evvel 1927, s. 1. 
uzun sürecektir. Bu ifasını zaruri gördü̆̆̈̈m bir vazife olduğundan beni mazur göreceğinizi zannederim" "24 diyerek, 19 May1s 1919 tarihinden başlayarak dokuz yılın hesabını vereceğini konuşmanın başında açıklamıştır. Büyük Nutuk'u 1 Kasım tarihinde açllacak meclis yerine CHF kongresinde okuyarak Yeni Türkiye'nin biçimlendirilmesinde araç olarak kurmuş olduğu partisine geçmişin hesabını vermiş, geleceğe ait de yol haritası çizmiştir. Kongredeki delegelerin tümünün desteğiyle Nutuk'ta anlatılanların onaylanması ise bir anlamda yapılan devrimlerin ve kongrede değişmez genel başkan seçilen Mustafa Kemal Paşa'nın siyasal liderliğinin kabulünün onaylanmasidır.

"Tarih yazmak, tarih yapmak kadar önemlidir. Yazan yapana sadik kalmazsa de ğişmeyen hakikat, insanlı ̆̆ şaşırtacak bir hal alır" sözleriyle tarihe bakışını dile getiren Mustafa Kemal Paşa, Büyük Nutuk'ta bir anlamda yaptığı tarihi yazma işini de kendisi üstlenerek Milli Mücadele'den başlayarak Cumhuriyet'in ilanı, Yeni Türkiye'nin kurulması ve yaşatılması için yapılanları (Milli Mücadele'nin başından itibaren 1927 yılına kadar yaşananları yani kurulan ulusal ve çağdaş devletin -kendi ifadesiyle Yeni Türkiye'nin- kuruluş öyküsünü) milletiyle/halkıyla paylaşmıştır.

Cumhuriyet Halk Fırkası Kongresi'nde okunan Büyük Nutuk, yaygın ve yerel basında tarihi bir olay kabul edilerek kongreden daha öncelikli işlenmiş, haberler genelde çerçeve içine alarak vurgulanmış, Nutuk'un okunmasından sonra da kongreyle ilgili haberler yanında Büyük Nutuk'la ilgili makale ve haberler devam etmiştir. Bu haberlerde genelde Mustafa Kemal Paşa ile Cumhuriyet rejimi özdeşleştirilmiş, Mustafa Kemal Paşa'yı sevmenin Cumhuriyet rejimini sevmek ve benimsemekle eş olduğu vurgulanmıştır.

Yaygın basın yapmakla sorumlu bulunduğu olayları haber verme, gelişmeleri topluma aktararak kamuoyunu bilgilendirme gibi görevleri yerine getirirken son derece titiz davranmış; neredeyse kitlelere ulaşmada tek iletişim aracının gazete olduğu yıllarda üzerine düşen sorumluluğu yerine getirmiştir.

Yerel basın ise Milli Mücadele yıllarında gösterdiği başarıyı Cumhuriyetin ilanından sonra devam ettirememiştir. Haberler -bazı gazeteler hariç- resmi gazete formatında Anadolu Ajansı'ndan alındığı şekliyle kopyala yapıştır da diyeceğimiz bir tarzda okuyucuya sunulmuştur. Bunda teknik olanaksızlıklar ve kadro eksikliği yanında basıldığı yerlerde dahi yerel basından çok yaygın basının gazetelerinin okunulması da etkili olmuştur. Yerel basın gözden geçirildiğinde genelde haberler Anadolu Ajansı'ndan alındığı için gazeteler farklı yerlerde yayınlansa da haberler

\footnotetext{
${ }^{224}$ Akşam, 16 Teşrinievvel 1927, s. 1.
} 
birbirinin aynı denecek kadar benzerlik göstermiş, Büyük Nutuk ve CHF büyük kongresi ile ilgili en ayrıntılı haberler Açısöz, Ahenk, Babalık ve Hizmet gazetesinde yer almıştır.

15-21 Ekim 1927 tarihleri arasında CHF İkinci Kongresi'nde okunan Büyük Nutuk gazetelerde ayrıntılı bir şekilde ele alınmasının ardından kısa bir süre sonra kitap olarak yayınlanmıştır. O tarihten günümüze kadar da okunmaya ve kaynak olarak kullanılmaya devam etmektedir.

\section{KAYNAKÇA}

Ahmad, Feroz, Modern Türkiye'nin Oluşumu, Kaynak Yayınları, İstanbul, 1999.

Ahmad, Feroz, Bir Kimlik Peşinde Türkiye, (Çev: Sedat Cem Karadeli), İstanbul Bilgi Üniversitesi Yayınları, İstanbul, 2006.

Arar, İsmail, “Büyük Nutkun Kapsam1, Niteliği, Amacı”, Atatürk’ün Büyük Söylevinin 50. Yll Semineri, Türk Tarih Kurumu Yayınları, Ankara, 1980, s. 119-171.

Arıkan, Zeki, "Büyük Söylev'in Yankıları", "Nutuk" Nedir, Ne Değildir, Der.:Ahmet Köklügiller, IQ Kültür Sanat Yayıncılık, İstanbul, 2005, s. 407427.

Atay, Falih Rıfkı, Çankaya, Pozitif Yayınları, İstanbul, 2004.

Atatürk, Kemal, Nutuk 1919-1927, Bugünkü Dille Yayına Haz.: Zeynep Korkmaz, Atatürk Araştırma Merkezi, Ankara, 2006.

Atatürkçülük (Birinci Kitap): Atatürk'ün Görüss ve Direktifleri, Milli Eğitim Basımevi, İstanbul.

Aybars, Ergun, İstiklal Mahkemeleri, C. 1-2, Dokuz Eylül Üniversitesi Yayınları, İzmir, 1988.

Aydeniz, Hediyetullah, "Tarihsel ve Literal Açıdan Yerel Gazetecilik”, Türkiye'de Yerel Basın, İstanbul Üniversitesi İletişim Fakültesi Yayınları, İstanbul, 2007, s. 1-27.

Bila, Hikmet, CHP Tarihi 1919-1979, Doruk Matbaacılık, Ankara, 1979.

Çebi, Murat Sadullah, "Türkiye'de Siyasal Sistem ve Medya İlişkilerinin Tarihi Boyutu", Yeni Türkiye Dergisi Cumhuriyet Özel Sayısı, IV/23-24, (EylülAralık 1998), s. 2746-2751.

Demirel, Ahmet, "Birinci Mecliste İktidar ve Muhalefet", Yeni Türkiye Dergisi Cumhuriyet Özel Saylsı, IV/23-24, (Eylül-Aralık 1998), s. 289-311. 
Er, Turgut, Türkiye'de Basın Yayın ve Tanıtma, Basın-Yayın ve Enformasyon Genel Müdürlüğ̈̈u, Ankara, 2003.

Feyzioğlu, Turhan, “Türk Basınının Kaderi”, Demokrasiye ve Diktatörlüğe Dair, İstanbul Matbaacılık, İstanbul, 1957.

Giritli, İsmet, “Okunuşunun 75. Yılında Büyük Nutuk”, Yetmişbeşinci Yılında Büyük Nutuk’u Anlayarak Okumak Bilgi Şöleni (17-18 Ekim 2002 Ankara), Atatürk Araştırma Merkezi, Ankara, 2003.

Güneş, İhsan, Birinci TBMM’nin Düşünce Yapısı (1920-1923), Türkiye İş Bankası Yayınları, Ankara, 1997.

Güz, Nurettin, Türkiye’de Basın-İktidar İlişkileri (1920-1927), Turhan Kitabevi, Ankara, 2008

İnan, Afet, Atatürk Hakkında Hatıralar ve Belgeler, Türkiye İş Bankası Yayınları, 2007.

Karal, Enver Ziya, “Açış Konuşması”, Atatürk’ün Büyük Söylevi’nin 50. Yılı Semineri, Türk Tarih Kurumu, Ankara, 1980.

Kabacalı, Alpay, Başlangıçtan Günümüze Türkiye’de Basın Sansürü, Gazeteciler Cemiyeti, İstanbul, 1990

Kabacalı, Alpay, Türk Basınında Demokrasi, Kültür Bakanlığı, Ankara, 1994.

Kardeş, Fethi, 60 Yılın Hikayesi, Ankara, 1980.

Karpat, Kemal H., Türk Demokrasi Tarihi, Afa Yayınları, İstanbul, 1996.

Kocabaşoğlu, Uygur, “1919-1938 Dönemi Basınına Toplu Bakış”, A.Ü. Siyasal

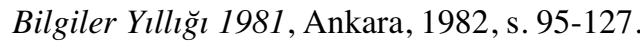

Kocatürk, Utkan, Doğumundan Ölümüne Kadar Kaynakçall Atatürk Günlü̆̆ü, Atatürk Araştırma Merkezi, Ankara, 2007.

Koloğlu, Orhan, Osmanlı'dan Günümüze Türkiye'de Basın, İletişim Yayınları, İstanbul, 1992.

Koloğlu, Orhan, Osmanlı'dan 21. Yüzyıla Basın Tarihi, Pozitif Yayınları, İstanbul, 2006.

Kongar, Emre, "Söylev Hangi Koşullar Altında Söylendi”, Türk Dili Dergisi, Söylev Özel Sayısı, XXXVI/314 (1 Kasım 1977), s. 374-380.

Kurat, Yuluğ Tekin, “Büyük Nutuk’un Okunduğu Yılın Türkiyesi: 1927”, 70. Yılında Ulusal ve Uluslararası Boyutlarıyla Atatürk'ün Büyük Nutuk'u ve Dönemi, Orta Doğu Teknik Üniversitesi, Ankara, 1999, s. 171-176.

Öztoprak, İzzet, Kurtuluş Savaşı'nda Türk Basını, Türkiye İş Bankası Kültür Yayınları, Ankara, 1981. 
Selek, Sabahattin, “Atatürk ve Büyük Nutuk", “Nutuk” Nedir, Ne De ğildir, Der.:Ahmet Köklügiller, IQ Kültür Sanat Yayıncılık, İstanbul, 2005, s. 51-58.

Şimşir, Bilâl N., Atatürk'ün Büyük Söylevi Üzerine Belgeler, Ankara, 1991

Tartanoğlu, Ali, “Atatürk Dönemi Türk Basınının Niteliği”, Baskın Basın’ın, Çağdaş Gazeteciler Derneği, Ankara, 1994.

Topuz, Hıfzı, II. Mahmut'tan Holdinglere Türk Basın Tarihi, Remzi Kitabevi, İstanbul,2003.

Tunaya, Tarık Zafer, Türkiye'de Siyasal Partiler 1859-1952, İstanbul, 1952.

Tunaya, Tarık Zafer, Türkiye'de Siyasal Partiler, C. 3, İletişim Yayınları, İstanbul, 2007.

Tunçay, Mete, “Cumhuriyet Halk Partisi (1923-1950)”, Cumhuriyet Dönemi Türkiye Ansiklopedisi, C. 8, İletişim Yayınları, İstanbul, t.y., s. 2019-2024.

Tunçay, Mete, Türkiye Cumhuriyeti’nde Tek Parti Yönetiminin Kurulması 19231931, Tarih Vakf1, İstanbul, 2005.

Tural, Sadık, “Aydınlar Büyük Nutuk'u Anlayarak Yeniden Okusalar", Yetmişbeşinci Yılında Büyük Nutku Anlayarak Okumak, Bilgi Şöleni 17-18 Ekim 2002 Ankara, Atatürk Araştırma Merkezi Yayınları, Ankara, 2003.

Tural, Sadık, "Büyük Nutuk’un Sahibi Yüce Şahsiyet”, 10 Kasım 2007 Atatürk’ü Anma Töreni Konuşmaları, Yay. Haz.: Zeki Dilek, Atatürk Araştırma Merkezi Yayınları, Ankara, 2008.

Uyar, Hakkı, Tek Parti Dönemi ve Cumhuriyet Halk Partisi, Boyut Yayınları, İstanbul, 1999.

Uyar, Hakkı, “Atatürk Dönemi İç Politikası”, Yakın Dönem Türk Politik Tarihi, Anı Yayıncilık, Ankara, 2006, s. 45-74.

Uzun, Hakan, Atatürk'ün Nutuk'unun İçerik Analizi, Hacettepe Üniversitesi Atatürk İlkeleri ve İnkılap Tarihi Enstitüsü, Yayınlanmamış Doktora Tezi, Ankara, 2005.

Ünder, Hasan, “Atatürk İmgesinin Siyasal Yaşamdaki Rolü”, Modern Türkiye’de Siyasi Düşünce: Kemalizm, C. 2. , İletişim Yayınları, İstanbul, 2001, s. 38-155.

Zürcher, Erik Jan, Milli Mücadelede İttihatçılık, Bağlam Yayınları, İstanbul, 1995.

Zürcher, Erik Jan, Modernleşen Türkiye’nin Tarihi, İletişim Yayınları, İstanbul, 2001.

Zürcher, Erik Jan, Terakkiperver Cumhuriyet Fırkası (1924- 1925), İletişim Yayınları, İstanbul, 2007. 


\section{Gazeteler}

Akşam

Cumhuriyet

Hâkimiyet-i Milliye

İkdam

Milliyet

Vakit

Açıksöz

Ahenk

Amasya

Babalık

Balıkesir

Bartın

Çankırı

Güzel İnebolu

Haber

Hizmet

Hür Fikir

Kizılırmak

Malatya

Mamuratül Aziz

Milli Gazete

Tarsus

Urfa

Yeşil Giresun

Yozgat. 